\title{
SETTLEMENT CONTINUITY AT SUŠINE SITE NEAR VIRJE (NORTH CROATIA) THROUGHOUT THE MIDDLE AGES
}

\author{
Tajana Sekelj Ivančan - Tatjana Tkalčec
}

DOI: 10.17846/CL.2018.11.2.35-66

\begin{abstract}
SEKELJ IVANČAN, Tajana - TKALČEC, Tatjana. Settlement Continuity at Sušine Site near Virje (North Croatia) Throughout the Middle Ages. The work discusses archaeological material from two archaeological units excavated within trench S-8 at the site of Virje-Sušine. On the basis of detailed analysis of fragments of pottery vessels and several metal objects, two horizons of settlement were recognised at this site during the Middle Ages: earlier - second half of the 8th and beginning of the 9th centuries and later - 11th century and the beginning of the 12th century. In the earlier horizon processing of iron ore and smelting were essential economic activities at the site.
\end{abstract}

Keywords: Virje-Sušine, settlement, pottery, bronze strap end, Early Middle Ages, High Middle Ages

\begin{abstract}
Abstrakt: SEKELJ IVANČAN, Tajana - TKALČEC, Tatjana. Sídelná kontinuita na lokalite Sušine, blízko Virje (severné Chorvátsko), počas stredoveku. Práca pojednáva o archeologickom materiály z dvoch archeologických objektov skúmaných v rámci sondy S-8 na nálezisku Virje-Sušine. Na základe detailnej analýzy fragmentov keramických nádob a niekolkých kovových predmetov boli počas stredoveku na spomínanom nálezisku rozpoznané dva sídelné horizonty: skorší - od druhej polovice 8. storočia do začiatku 9. storočia a neskorší - od 11. storočia do začiatku 12. storočia. V skoršom horizonte boli základnými ekonomickými činnostami na danom nálezisku spracovanie železnej ruky a jej tavba.
\end{abstract}

Klúčové slová: Virje-Sušine, sídlisko, keramika, bronzové nákončie, včasný stredovek, vrcholný stredovek

During the several years of archaeological excavations at the site of Sušine at Virje, a large archaeological unit was investigated within trench S-8, whose contents indicated that life continued at this site throughout several medieval centuries. ${ }^{1}$ At this archaeological site, located in the lowlands of the Drava River (Map 1), in addition to medieval structures and features (Sekelj Ivančan 2017b, 2018), some features were also investigated from the Late Iron Age (Sekelj Ivančan Karavidović 2016), as well as structures and features related to economic activities that took place throughout Late Antiquity at this site, or in relation to smelting iron ore (Sekelj Ivančan - Mušič

1 Archaeological excavations at Virje were performed in the period from 2008 to 2014, on the basis of which the foundations were laid for the scientific research project called TransFER. After the project began to be financed, a detailed analysis of the collected material was undertaken as well as drawing the material. The separated finds and their analysis have thus been undertaken in the framework of the scientific research project TransFER - The Production of Iron along the Drava River in Antiquity and the Middle Ages: the creation and transfer of knowledge, technology, and goods (IP-06-2016-5047), financed by the Croatian Scientific Foundation, and carried out by the Institute of Archaeology. 
2014). Features from the Post Medieval period were also discovered. ${ }^{2}$ The subject of this work, however, is an analysis of the portable material from the large archaeological unit, e.g. larger feature with several stratigraphic units, and from the interrelated smaller feature with a circular plan excavated in trench S-8. The numerous fragments of pottery vessels and the occasional metal object from the larger ensemble pointed to the chronological variety of material within the feature itself, while during excavations it was noted that parts of the feature also differ in terms of the colour or consistency of the soil, and they were distinguished as separate strata, while the finds were separated, so that their relations could ultimately attempt to be distinguished.

\section{The circumstances of discovery of archaeological features}

The large archaeological unit discussed here was located within the Trench 8 , with a total excavated area of around $74 \mathrm{~m}^{2}$ (fig. 1). The trench was opened on the basis of the results of earlier geophysical investigations, at the spot where anomalies were noted in the form of large oval-rectangular red splotches (Mušič et al. 2013).

After removal of the ploughed humus layer, a sandy yellow layer was found where a large oval stratum was noted of dark brown sandy soil, extending lengthwise E-W (SJ 315: thickness $33 \mathrm{~cm}$; dimensions of the pit SJ 316: 6.07 x $3.11 \mathrm{~m}$ ). After removal of the surface section of this dark brown soil, in the southwestern section the stratum was composed of a somewhat darker soil, almost black, which contained a considerable quantity of daub and broken slag, as well as fragments of a pottery tuyere (SJ 318: thickness $28 \mathrm{~cm}$; dimensions of the pit SJ 325: $2.61 \times 2.31 \mathrm{~m}$ ), while in the more eastern section, it had a lighter brown colour (SJ 320: thickness $28 \mathrm{~cm}$; dimensions of the pit SJ 326: $2.15 \times 1.92 \mathrm{~m}$ ). Both strata were excavated independently and the finds are separated from one another. The space between stratum SJ 318 and stratum 320 also had a paler colour (SJ 319), very similar to stratum SJ 315 in the upper part, and a paler colour was also on the surface further to the west (SJ 324) of the almost black stratum SJ 318 (SJ 324: thickness $28 \mathrm{~cm}$; dimensions of the pit SJ 391: $1.44 \times 103 \mathrm{~m}$ ), as well as the surface northwest (SJ 336) of SJ 318 (SJ 336: thickness $39 \mathrm{~cm}$; dimensions of the pit SJ 316+390: 7.13 (E-W) x 4.15 (N-S) m).

Southwest of the larger feature was a circular stratum of paler brown soil with fragmented daub in the upper section, with dark burnt material near the surface, while near the bottom were large pieces of fired daub (SJ 330: thickness $38 \mathrm{~cm}$; dimensions of the pit SJ 331: 0.76 x $0.57 \mathrm{~m}$ ).

Soil samples were taken from all strata (e.g. fills of features) during excavations. Floatation with two sieves was carried out to analyse the archaeobotanical remains, which gave very modest results. ${ }^{3}$ All the samples contained non-carbonised seeds of lamb's quarters (Chenopodium album L.), and one un-carbonised (SJ 318) and one carbonised (SJ 319) seed of pale smartweed (Polygonum lapathifolium L.), as well as several seeds of undefined species. Only in one case (SJ 320), were the carbonised seeds recognised of a cultivated plant, millet (Cf. Panicum miliaceum L.). As the majority of material consisted of weeds, this analysis did not enable any

${ }^{2}$ The analysis of the radiocarbon (C14) sample 182 from SJ 304 was carried out in the ${ }^{14} \mathrm{CHRONO}$ Centre, Queens University Belfast, Northern Ireland, as Chrono UBA-35131. Results: Conventual Radiocarbon Age: BP 301 \pm 27 ; One Sigma Calibrated result (68\%): Cal AD 1521-1575; Cal AD 1625-1646; Two Sigma Calibrated result (95\%): Cal AD 1492-1602; Cal AD 1615-1651.

3 The analysis was carried out by Renata Šoštarić, PhD, from the Botanical Institute of the Natural History and Mathematics Faculty of the University of Zagreb, for which we are sincerely grateful. The analysed samples: U 134 - both fractions, U 135 and U 136 - only one fraction, and U 161 - both fractions (SJ 318, 320,319 , and 336). Samples U 150 from SJ 330 and U 181 from SJ 336 did not contain archaeobotanical remains. 
concrete conclusions about the growing, harvesting, or consummation of plants throughout the existing of this feature.

While excavating all the strata of the large unit, charcoal was also collected in order to determine the types of wood utilised in construction of the possible wooden building, as well as to enable dating through radiocarbon analysis. Most cases consisted of fragments of oak (Quercus - 42 specimens + tiny fragments), ${ }^{4}$ while two other species were present in two strata: SJ 319 - beech (Fagus - 3 spec.) and cherry (Prunus avium - 2 spec.), along with maple in stratum SJ 320 - (Acer 5 spec.). Fragments of maple wood were also found at this site in another two medieval features at Sušine (Sekelj Ivančan 2017b), and in one prehistoric feature excavated at the nearby position of Volarski breg at Virje (Sekelj Ivančan - Botić - Culiberg 2018), while charcoal fragments classified as beech and cherry were only present in the above stratum. On the other hand, in the smaller feature (SJ 330) discovered by the larger one, in addition to oak (2 specimens), other types of wood were discovered, such as ash (Fraxinus - $4 \mathrm{spec}$.), elm (Ulmus - $1 \mathrm{spec}$.), and hornbeam (Carpinus - 4 spec.). These are all species that also appear in other features at Sušine (Sekelj Ivančan 2017b), but also in the prehistoric formations found at Volarski breg (Sekelj Ivančan Botić - Culiberg 2018). Altogether it can be concluded that although all the pieces of charcoal were very small, the numerically highest representation was of oak, which was most probably used as building material, while the other species were sporadically present, and in the case of the small formation where several types of wood were noted, and considering the fact that the upper section were full of burnt remains (soot), perhaps they served as fuel resources (Sekelj Ivančan - Botić Culiberg 2018). A charcoal sample (U 145) was utilised to make a C 14 analysis, which for stratum SJ 320 gave the date BP $1216 \pm 23$, and alternatively according to Online CalPal the date Cal AD $811 \pm 41 . .^{5}$

There were remarkably few remains of animal bones in all strata of the larger archaeological unit, as well as the connected smaller feature (only one undefined fragment in SJ 320), which was probably the result of soil acidity that did not allow bones to be preserved. Only two fragments of the molars of small ruminants were preserved (SJ 315 and 319). ${ }^{6}$

From all strata of the larger archaeological unit, 17 fragments of stone were collected $(961 \mathrm{~g})$. Some fragments, although very small, can be attributed to a grindstone or quern in terms of structure and appearance, with only one somewhat larger piece preserved (SJ 315: 1.: $110 \mathrm{~mm}$, w.: $70 \mathrm{~mm}$, th.: $26 \mathrm{~mm}$, wt.: $217 \mathrm{~g}$ ), partly with a rounded shape, indicating that it was the edge of the quern (PN 63 - fig. 2). Two fragments of stone, one grey (SJ 315: 1.: $50 \mathrm{~mm}$, w.: $24 \mathrm{~mm}$, ht.: $22 \mathrm{~mm}$, wt.: $56 \mathrm{~g}$ ) and the other ochre (S 001/336: 1.: $37 \mathrm{~mm}$, w.: $31 \mathrm{~mm}$, ht.: $26 \mathrm{~mm}$, wt.: $35 \mathrm{~g}$ ), each have one or two polished surfaces, and can be assumed to be fragments of whetstones (fig. 3).

In addition to the abundance of pottery fragments from ordinary cooking pots and other objects of everyday use that will be discussed later, ${ }^{7}$ during the excavations quite a lot of fired daub

4 The basic determination of the type of wood from the charcoal was performed by Metka Culiberg, $\mathrm{PhD}$, of the Biological Institute "Jovan Hadžija", Scientific Research Center SAZU, Ljubljana - now retired, for which we would like to thank her.

${ }^{5}$ The analysis of the radiocarbon (C14) sample 145 from SJ 320 was performed at ${ }^{14} \mathrm{CHRONO}$ Centre Queens University Belfast, Northern Ireland, as Chrono UBA-27790. Results: Conventual Radiocarbon Age: BP 1216 \pm 23 ; One Sigma Calibrated result (68\%): Cal AD 770-779; Cal AD 789-868; Two Sigma Calibrated result (95\%): Cal AD 715-743; Cal AD 765-886.

6 The analyses were carried out by Snježana Kužir, $\mathrm{PhD}$, and Tajana Trbojević Vukičević, PhD, of the Veterinary Faculty of the University of Zagreb, for which we sincerely thank them. The samples U 133, U 140, and U 148 were analysed.

7 It should be mentioned that in the strata SJ 315, 318, and 320 were found three very tiny fragments of pottery ( 3 pieces / $74 \mathrm{~g}$ ), which can otherwise be found at the site of Sušine within archaeological units 
and broken slag was collected that displayed various characteristics (Table 1). The analysis showed that there were varied fragments that were classified into several groups, ${ }^{8}$ for example, fragments of slag from smelting and blacksmithing were separated, as well as fragments of furnace walls, ${ }^{9}$ and also small pieces of iron and ore. On the basis of the macroscopic analyses undertaken, it can be established that the great majority of these fragments, otherwise connected to the smelting activities at this site, were found in strata SJ 315 and 318 (total of almost $55 \mathrm{~kg}$ ), almost three times more than in all the other excavated strata of the larger feature (Table 1). It was also noted that the slag displaying traits of discards from blacksmithing had been discovered solely in stratum SJ 318 (ca. $2 \mathrm{~kg}$ ). Finds of fragments of ceramic nozzles (tuyeres) should also be added to this (51 fragments), ${ }^{10}$ which were mostly also found within the above mentioned stratum and in SJ 324 (Table 2), while they only appear sporadically in the other strata (SJ 319, 320 and 336), or in the smaller feature (SJ 330), or they do not appear at all. If they do not in fact represent secondary finds in the later feature, the presence of large quantities of this specific type of waste in certain strata (SJ 315, 318, and 324) leads to consideration of the connection of such finds with a place where activities took place related to iron processing or blacksmith activity.

\section{The basic characteristics of the finds}

The greatest amount of data about the period of existence of the archaeological features discovered in trench 8 is offered by the pottery and metal objects. Therefore, special attention will be directed to the analysis of basic features, as well as the details of medieval pottery material, in order for the differences in individual segments indicate an exact dating. ${ }^{11}$ All of the finds were separated already during the archaeological excavations, as in the field, as has already been noted, it was seen that certain differences existed in the colour and consistency of the soil from which they came. In this manner, six strata were distinguished within the larger archaeological unit. The pottery finds from them are discussed according to the numbers of the strata, from smaller to larger (Pl. 1-8), while the metal objects from these strata are discussed later (Pl. 8: 80, 81; 9: 82-86). ${ }^{12}$

from the High Middle Ages in considerable quantities (Sekelj Ivančan 2018), and they probably arrived at this site thanks to chance and/or later interventions.

8 The macroscopic analysis of all these finds was carried out by our colleague Ivan Marija Hrovatin, BA, from Trieste, whom we would like to thank. The detailed analysis of all finds related to smelting activities at this site will be performed subsequently.

9 Among the multitude of amorphous forms of fired daub, several examples were noted that in their fabric and form displayed other characteristics. These consisted of a fragment of a Roman tile $(85 \mathrm{~g})$ and piece

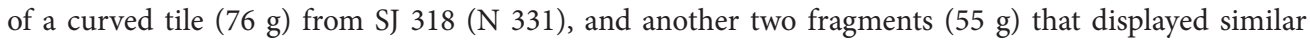
characteristics to the latter from SJ 320 (N 740). Stratum SJ 288 contained one more such fragment (60 g; $\mathrm{N}$ 739). All the cited examples here represent secondary finds of earlier (Roman) layers.

10 The exceptional fragmentary nature of the finds meant it was not possible to determine the minimal number of tuyeres at this feature, but the fragments all had a different colour ( from ochre to red, in various tones) and forms.

11 As Sušine is in fact a multilayered archaeological site, all the layers contained some pottery fragments from earlier times (prehistory/antiquity - a total of 423 pieces / $2875.8 \mathrm{~g}$ ): SJ 315 (64 pieces / $370.2 \mathrm{~g}$ ); SJ 318 (43 pieces / 454 g); SJ 319 ( 86 pieces / 620.8 g); SJ 320 (42 pieces / 236.1 g); SJ 324 (25 pieces / 231.5 g); SJ 001/336 (67 pieces / 632.1 g); SJ 336 (90 pieces / 293.7 g); SJ 330 (6 pieces / 37.4 g).

12 The author of all the drawings is Suzana Cule. The conservation of the metal finds was performed at the Croatian Conservation Institute in Zagreb. 


\section{Pottery finds}

In the analysis of the pottery material, we will primarily deal with the functional forms of the vessels found, followed by their basic features. Particular attention will be paid to the shape of the vessel rim and to the decoration, in reference to the type of decoration and its location on individual parts of the vessel. Details about the fabric and the manner of production will also be noted. Such studied details of the collected material enables viewing chronologically distinct features and offers a more accurate chronological determination of the analysed material.

A total was collected within all strata of the large archaeological unit of 1265 pottery fragments $(14440.9 \mathrm{~g})$, while in the smaller one there were only 24 fragments $(345.8 \mathrm{~g})$. Of functional forms of vessels, everyday kitchen pots were most represented, while fragments were also present that could be related to circular baking trays that could have served for baking bread (Backteller, Tonscheibe) or rectangular racks that would have functioned as grain dryers (Tonwanne). ${ }^{13}$

An attempt was made to establish the minimal number of used ordinary kitchen pots in the analysed material from the excavated unit, or in fact from all strata, which were classified on the basis of differences in form, fabric, decoration, etc., however the acquired number of as many as 109 examples would certainly not indicate their everyday use in a given period, as this significantly exceeds the usual number of utilised vessels in a dwelling structure. Hence the question arises as to whether this refers to various periods of functioning of individual strata/pits/structures and translocational/vertical stratigraphy, or even material discarded into a waste pit at a certain time. Answers to these questions are offered by thorough analysis of the details on the pottery vessels. What can be immediately noted in the basic macroscopic examination of the pottery material are the major differences in the fabric of the fragments. On the one hand, the fragments have an exceptionally coarse fabric with considerable admixtures of small and large granular stones irrespective of the assumed size of the vessel, ${ }^{14}$ while on the other hand, finer fabric with admixtures of grains of sand are also found in large quantities. ${ }^{15}$ It can additionally be noted that the fragments with a finer fabric mostly have an ochre colour, while those with coarse fabric come in various colours, from red, and brown, to dark grey, as well as various nuances of ochre.

The difference in the fabric consistently corresponds to the difference in the formation of the more or less everted rims of the vessels. ${ }^{16}$ On the one hand, they have simple molding with a rounded (nos. 2, 20, 22) or sharp cut rim (nos. 1, 3, 6, 7, 21, 23, 26, 34, 45, 46, 47, 51, 52, 72), while on the other hand, rims appear that could be considered as transitional forms from simple towards the so-called Kragen (collar) rims (nos. 5, 8, 24, 35, 36, 38), and slightly divided rims (nos. 48,49 ) with a rounded lower lip (nos. $4,73,74$ ), while the so-called chalice-type (Kelchen) rims

13 Because the pieces are so fragmentary, it cannot be established with certainty whether these are circular baking trays or square drying trays, which is very difficult to determine on the basis of the fabric alone. For this reason, both functional forms are noted.

14 The exceptional fragmentary nature of the pottery fragments meant that the majority of vessels could be more precisely determined on the basis of the rim diameter only as several types of pots. The measurement of the rim diameter of a pot, on the basis of which it is possibly to determine the volume or capacity of the vessel, and their classification according to group were carried out according to the model introduced by A. Pleterski (2011). Most of them had medium dimensions (nos. 4, 22, 23, 46, 47, 48, 50, $63,73,74$ ) and small dimensions (nos. $1,3,8,34,35,36,45,72$ ), while larger pots were not represented to such an extent (nos. 20,21, 49, 74).

15 Fragments with coarse fabric - nos. 1, 9, 11, 12, 13, 16, 20, 21, 22, 23, 24, 26, 28, 29, 30, 32, 33, 41, 42, 51, $52,57,58,60,61,65$, 75. Fragments with finer fabric - nos. 3, 4, 5, 6, 7, 8, 18, 36, 37, 38, 40, 43, 44, 46, 47, $48,49,50,53,54,55,56,59,64,66,68,69,70,71,72,73,74,76,77,78,79$.

16 It was not possible to reconstruct a single entire vessel from all of the presented pottery material and hence the difference in the formation of whole pots could not be observed. 
were completely absent. From the above, a specific shape of the rim of a pot should be noted (no. 27), which can also be found at other features in Virje from the early medieval period, such as at Volarski breg (Sekelj Ivančan 2017a, Pl. 4: 25), and also Sušine (Sekelj Ivančan 2017b, 118, 125, Pl. 1:2,3). The fabric of this rim fragment from a pot (no. 27), where the exterior part of the rim is emphasised and slightly lowered in relation to the entire rim, with a shallow groove on the upper side of the rim, is smooth on the surface, although the structure contains a considerable admixture of tiny stones. It is close in form and fabric to fragment no. 63, whose analogy can be found in the mentioned vessel rim from Volarski breg. In contrast to this, fragments with a similarly shaped rim, but without the groove on the upper surface, and the emphasised element on the inner side of the rim, have a quite different fabric (nos. 25, 37, 50). This is a more refined, but still granular fabric. The fragments are ochre-brick coloured on the exterior walls, and grey in cross-section. The above vessels, among which nos. 25 and 37 are also identical, were made on a fast potter's wheel. If rims shaped in this manner, which appear on vessels in the early medieval period, were also retained in the later period of the High Middle Ages, and would perhaps represent a type of characteristic vessel for this region throughout a lengthy period, can be concluded only when there will be more investigated archaeological units with precisely dated material in the broader area around Virje.

A connection was noted in the analysis between the specific fabric and specific manner of manufacturing the vessels. The vessels with a coarse fabric were made with a slower wheel, after which some finishing touches were necessary on the still moist clay vessels. Subsequent refinishing by hand is visible on some pieces in the form of perpendicular traces of smoothing on the inner sides of the vessels (nos. 11, 20, 22, 23, 26, 28, 29, 30, 32, 33, 34, 42, 46, 58, 67, 75), while an imprint of the axis of the wheel is present on several fragments in the form of a deepened hollow on the lower surface of the base (nos. 9, 28), which is a characteristic of the manufacture of vessels on a slow potter's wheel. ${ }^{17}$ In contrast to this, vessels with finer fabric mostly have no such traces on the walls, only vessel no. 46 shows visible refinishing on the interior walls, while most of the bases are either flat standing surfaces or more rarely annular rims on the edges of the flat base, without any marks. ${ }^{18}$ This group of vessels with finer fabric was made on the fast potter's wheel. Three vessels whose fabric could not be assigned to either of our two groups above (so-called middle fabric: nos. $34,67,75$ ), also have visible traces of subsequent smoothing visible on the inner side of the walls, and according to the other characteristic they should rather be connected to the examples with coarse fabric made on a slow potter's wheel, instead of the vessels of finer fabric made on a fast potter's wheel.

The decoration of the vessels was varied, both in terms of the manner and type of decoration, as well as the position of a given decoration on individual parts of the vessels. Related to the position of the decoration, it should be noted that the decoration of combed wavy lines stands out on the inner side of the rim of pot no. 34, and on the exceptionally fragmented pieces nos. 51 and 52, where no. 51 was also decorated on the exterior side. All three fragments belong to vessels with relatively coarse fabric made on a slow wheel, which can particularly be concluded for the better preserved upper part of the pot, considering the visible interior perpendicular

17 Others with coarse fabric made on a slow potter's wheel were nos. 1,10 ?, $12,13,16,21,24,31,41,45$ ?, 51 , $52,57,60,61,65$.

18 Because of the exceptionally fragmentary nature of the straight and annular bases, they were not depicted in the drawings. For the same reason, it cannot be stated with certainty that this unit did not contain pots with marks on the base, but they are not present in the available material - perhaps they simply were not discovered during the archaeological excavations. 
smoothing (no. 34). ${ }^{19}$ Although in general it could be said that in terms of decoration irregular combed wavy lines predominate on the coarse fabric vessels (nos. 11, 12, 13, 21, 22, 23, 24, 30, $31,32,33,41,45,57,58,61,65)$, which appear alone or in combination with combed horizontal lines ${ }^{20}$ in fact fragment no. 34 stands out for its different decoration. These were square shallow notches made with a comb-like object in groups with a rhomboid appearance, which are located on the shoulder of the pot (no. 34). Similar notches also made with a comb-like object, but in irregularly arranged lines, can be found on a fragment of the body of a fine fabric vessel made on a fast wheel (no. 79). It seems that although at first glance they are similar, these two manners of decoration by incision (nos. 34 and 79) cannot be considered directly connected, as they neither reflect the same period nor the same manufacturing process. Perpendicular comb-like notches are also located on the shoulder of another coarse fabric vessel, and below this a combed wavy line can again be found (no. 1), a combination of motifs that has been found at the sites of Prečno pole and Blaževo pole in Torčec (Sekelj Ivančan 2010, Pl. 16: 93; Pl. 32: 205; Pl. 38: 237), where they are dated to the 8th and the beginning of the 9th centuries, although the above decoration of perpendicular multiple lines, according to L. Bekić, would be the earliest decoration in the framework of early Slavic pottery, which appears in the first half of the 7th century (Bekic 2012, 24, Pl. 1: 7). In addition to being exceptionally irregular, the combed wavy lines on the above fragments are more deeply incised and have more varied amplitudes of the waves than on those with a more refined fabric, but some examples also have very thin combed incisions (no. 61), such as can be found at other sites in the Drava River valley region (Sekelj Ivančan 2010, Pl. 7: 33; Pl. 15: 87; Pl. 16: 92; Pl. 30: 190). Other motifs that should be mentioned include the horizontal incised line on fragment no. 27, as an isolated example of this motif on vessels with coarse fabric, which have close parallels in the above mentioned two vessels from the second early medieval feature at Sušine (Sekelj Ivančan 2017b, 125, Pl. 1: 2, 3).

On the other hand, bunches of horizontal lines often appear on fragments with a finer fabric (nos. 4, 19, 44, 53, 56, 59, 71), as well as combed wavy lines (nos. 3, 18, 40, 46, 50, 55, 66, 72, 76), alone or in combination (nos. $39,43,54,64,70$ ), but considerably more shallowly incised and more regularly made. Single wavy lines also appear (nos. $6,7,15,68$ ), as well as single horizontal lines in a row (nos. 17, 25, 62, 69, 78), motifs that are completely missing on vessels with coarse fabric. The only exception to this usual and almost uniform decorative repertory is a fragment with finer fabric where, between bunches of wavy lines (?) and straight lines, was a shallowly incised motif in the form of a palm branch (no. 77).

Reviewing the described details, it should be noted that the analysed pottery material from trench S-8 did not contain a single vessel made by hand, and that there was only one that was completely undecorated, but made on the wheel (no. 1). If comparisons are made to the thoroughly investigated and defined micro-units supported by radiocarbon dates in the vicinity of Torčec as the closest parallels to this site, these are the characteristics of pottery group 1, dated there from the end of the 6th to the middle of the 7th centuries (Sekelj Ivančan 2010,105-114), although vessels made by hand are present at other sites in the broader vicinity, where they are dated to the same time (Bekić 2012; 2016b, 94-95, fig. 51). The entire repertory also does not contain pots on whose external walls traces can be found of the spinning of a fast wheel in the form of dense horizontal "lines", a type of "decoration" that can be found on material from the second

19 Yet another vessel, but with finer fabric, was decorated on the outside rim (no. 4), but seemingly this was more a reflexion of the manufacturing process than a deliberately made decoration.

20 Bunches of horizontal lines were noted on some lower sections of coarse fabric vessels that are presumed to have had a decoration of combed wavy lines in the area of the shoulders and upper part of the body (nos. 10, 29). 
half of the 13th and the beginning of the 14th centuries from the Torčec micro-area, which served as a form of paradigm for our material. In this last Torčec pottery group $5 \mathrm{~b}$, red painting on a white base was also present, which was entirely lacking in the discussed material from Sušine (Sekelj Ivančan 2010, 136). It should further be emphasised that in the High Middle Ages, and hence in the last, fifth pottery group at Torčec (the 12th to the beginning of the 14th centuries), in addition to ordinary cooking pots, whose rimes acquired a chalice-shaped form, other functional forms were also present, such as jugs, ceramic cups, and plates (Sekelj Ivančan 2010, 111). All this was completely missing at Sušine. Therefore, on the basis of the described characteristics of the pottery, the chronological framework for all the pots from Sušine corresponds to the Torčec pottery groups 2, 3, and 4, which encompass the period from the second half of the 7 th to the beginning of the 12 th centuries.

In an attempt to chronologically classify this pottery in more detail, it was already noted that considerable differences exist in the pottery that evidently point to different periods of its utilisation. The first group of pottery, with a coarse fabric and various colours, made on a slow potter's wheel (small hollow on the lower standing surface of the base) with characteristic decorations on the shoulder and body, dominated by combed wavy lines, sometimes located on the rim itself, correspond completely to the characteristics of Torčec group 2, which encompasses the second half of the 7th and almost the entire 8th centuries (Sekelj Ivančan 2010, 115, fig. 99). Such characteristics are also present at other contemporaneous sites in the broader vicinity (Bekić 2016b, 99, 101, fig. 56), but also on the pottery from a previously published feature from this site that is dated to the same time (SJ 436: Sekelj Ivančan 2017b, Pl. 1-4). The second group of vessels with a finer fabric and an almost uniform ochre-grey colour, where a larger repertory of decoration appears, has close parallels to the Torčec pottery group 4. However, some differences do exist. While some other functional forms appear at Torčec in this group (Sekelj Ivančan 2010, 111, fig. 97: C, D, E, F, G, H), they were missing in our feature, as were the teardrop-shaped notches on the shoulder of the pots, which were characteristic for Torčec group $4 \mathrm{~b}$. Also missing was the otherwise popular decoration made with a small wheel, which was considerably represented in groups $4 \mathrm{a}$ and $4 \mathrm{~b}$ during the 11th and first half of the 12th centuries in the Torčec area (Sekelj Ivančan 2010, 127-134), and was otherwise also a popular decoration at other sites in northern Croatia dated to the transition from the Early to the High Middle Ages (Bekić 2010, 227-241). The complete absence of the small wheel decoration can be interpreted as an expression of a local "fashion", or differences in the preferences of the local master potters. Related to the absence of other functional forms of vessels other than pots, it should be mentioned that differences exist among the contemporaneous pottery discovered at Torčec at the site of Prečno pole and that from the site of Ledine (which together compose pottery group $4 \mathrm{a}$ ), where that difference is interpreted as the appearance of newly arrived inhabitants at the site of Ledine, who brought with them new forms for which parallels can be found in Hungary (Sekelj Ivančan 2010, 175). Finally, it should be emphasised that the teardrop-shaped decoration of the shoulders of pots that were not present in the features under discussion were nonetheless present at the site of Sušine, in three features located somewhat further to the south on the slope of the elevation, where chalice-shaped rims appear, as well as new functional forms of vessels/flasks with a narrow and ribbed neck (Sekelj Ivančan 2018, Pl. 1: 4). The material from these three features have the closest parallels with the Torčec pottery group $4 \mathrm{~b}$, however, the decoration of combed wavy lines was almost missing, while this is in fact significantly represented in the pottery with a finer fabric that is discussed here. Hence, the second group of pottery from trench S-8, which consists of vessel with a finer fabric made on a fast potter's wheel should be placed to the period immediately before the first such appearance of the above decoration and rim shape at Sušine, meaning that it immediately 
preceded the pottery material from the three features located further to the south along the slope that are dated in the framework of the 12th and first half of the 13th centuries.

Fragments tied to another functional form - baking or drying trays - were in fact the most represented in all strata within trench 8 , although they were also present in other features and strata at this site (Sekelj Ivančan 2017b, 120-121), however in considerably more modest amounts, where they arrived as a consequence of the lengthy inhabitation of this site (Table 3). This small trench contained 207 large and small fragments, with a total weight of around $4 \mathrm{~kg}$, which in terms of the smooth fabric with visible irregular hollows in the structure of some pieces (fig. 4), with parallels known from other sites in the vicinity (Bekić 2016b, 75, 107-108, fig. 41, 63; Sekelj Ivančan 2000, 73-74, fig. 4, 5), and the form and size, can be related directly to baking or drying trays. Some of them have a polished side (22 examples), while others are corner fragments (10 examples). Most come from stratum SJ 318 and from strata SJ 315 and 319, and their characteristics completely correspond to the baking or drying trays discovered at previously published early medieval features at this site (Sekelj Ivančan 2017b, fig. 4). These finds, tied to the preparation (drying) of grain and (baking) of bread, at the site of Sušine are further supplemented by the discovered fragments of stone that can be defined as a grindstone or quern (fig. 2), and together, although no archaeobotanical remains of cultivated plants are known (except millet in SJ 320), additionally indicate elements of the diet of the population that inhabited this site in the medieval period.

\section{Metal finds}

Metal objects of everyday use or parts of individual iron objects are very scarce, but nonetheless less they offer sufficient data for certain conclusions. Only one object stands out - a bronze strap end (SJ 315: ht.: $53 \mathrm{~mm}$, w.: $16 \mathrm{~mm}$, th.: $2 \mathrm{~mm}$, wt.: 8 g; PN 64 - Pl. 8: 80). This is a one-part cast belt strap end of rectangular shape, rounded in the lower section. It is quite smooth on the lower side, while on the upper side it is decorated with a motif of stylised circular or S-shaped tendrils placed in an incised rectangular frame. The upper section has a socket for placement of the belt, and at the top two holes for the rivets that served to attach the strap end to the belt. Its appearance at first glance shows that this find is from the early medieval period, and that it belongs to a group of objects related to the attire of male members of the community. This small cast strap end is not the main one, but rather auxiliary, one of the strap ends that were placed on the belt on the side. From its appearance it can be concluded that it was cast using a two-part mold, while the manner of its attachment to the belt with a socket and rivets, in fact the combination of the manner of production through casting and the mechanism of attachment to the belt using a socket and rivets indicates that the strap end could have been made in some transitional period between the times when strap end with sockets were used ${ }^{21}$ and those when strap ends attached only with rivets appeared (Stadler 1988/1989, 213, Pl. 4: 6). Almost identical strap ends were found at the cemetery of Tiszafüred in northeastern Hungary, where such side strap ends were placed by E. Garam in the 5th chronological phase of the cemetery and dated to the end of the 8th and beginning of the 9th centuries, in fact between 780 and 810 , with the possibility of a somewhat earlier appearance as well as a somewhat longer retention in use ( \pm 10 years; Garam 1985, fig. 96: 54/1221; fig. 254, Pl. 161: Gräber 1221: 5, 6, 7). Here it is necessary to note the deceased individual

21 The appearance of cast strap ends with a socket was noted, for example, in grave 4 at the Slavic Avar period site of Otok near Vinkovci together with sheet metal sets that were still in use, so the authors dated the above grave to the first decades of the 8th century because of the appearance of these objects with different manners of manufacture (Rapan Papeša - Šmalcelj Novaković 2016). 
from grave 13, discovered at the Avar period cemetery in Otok near Vinkovci, who was placed in the grave together with a rich belt set with a main strap end that in terms of construction has identical elements as the strap end from Sušine. It was cast in a one-part mold, and had rivet holes, but also a socket (Rapan Papeša - Šmalcelj Novaković 2016, 15-16, 33), meaning that the same mechanism for attachment to the belt was present on both strap ends, some kind of combination of two different manners of attachment. A second element that connects them is that both were single-part strap ends, which was not usual for this manner of production, as cast strap ends were two-part in most cases. The detailed analysis of all grave finds from this grave indicates that the burial of this prominent man, according the authors, would have occurred around the middle or second half of the 8th century. According to the mentioned analogies for the constructional elements, our side strap end could be from the period of the second half of the 8th century, which is additionally confirmed by the decoration of the circular tendrils. According to the analysis of the vegetal decorations in the Late Avar ornamentation undertaken by G. Szenthe for the area of the entire Carpathian Basin, this motif would correspond to the Alattyan decoration characteristic specifically for the second half of the 8th century (Szente 2013, 309, 314-315, Fig. 3, 9). A strap end decorated with very similar circular tendrils came from an unknown site in the vicinity of Križevci dated to the end of the 8th century, which represents the spatially closest analogy to our strap end, but with one difference - it was manufactured using the perforation technique (Katalog 2000, 90, II. 12a).

The other metal objects include the find of an iron belt buckle of trapezoidal shape, with an oval/ circular section (?), missing the prong (SJ 315: ht.: 3.3-4.3 mm, w.: $45 \mathrm{~mm}$, th.: 2-7 mm, wt.: $10 \mathrm{~g}$; PN 228 - Pl. 8: 81). On the narrow side, in the middle of the buckle, the place where the prong was attached is visible. The buckle is undecorated, while its dimensions place it among the larger forms. Trapezoidal (and square) iron buckles of large dimensions could have been part of attire (cf. Garam et al. 1975), but because of their discovery in Avar period equestrian graves placed by the animals are also often tied to horse equipment (Měchurová 1983, 88). When located in graves by the horse, they served to fasten the saddle girth, as was suggested in reconstructions based on the excavations at the cemetery of Tiszafüred by E. Garam (1987, 121-124). A very similar buckle was found by the burial of a horse in equestrian grave 13, and another by a horse in grave 14 at Brodski Drenovac, which are dated to the beginning of the 9th century (Vinski-Gasparini Ercegović 1958, 143, Pl. XII: 3; Pl. XIII: 3; Katalog 2000, 84-86, II. 3f; II. 4d).

Both objects described above, the side strap end and the buckle, come from the same context stratum SJ 315, while judging from their dates, or rather analogies with other well dated sites, this stratum could be placed in the second half or end of the 8th century, or at the latest to the beginning of the 9th century, as the cemetery at Brodski Drenovac was dated.

The iron objects, however, that were discovered in stratum SJ 320 were dated by radiocarbon analysis in a broad range from the beginning of the second half of the 8 th century to the middle or the beginning of the second half of the 9th century. These consisted of a small iron knife (PN 91 - Pl. 9: 84) and two pieces that could have belonged to the metal hoops of a wooden bucket. One piece is narrower and thinner and semicircularly shaped (PN 90 - Pl. 9: 86), while the other was broader, with the ends overlapping, and the place where the two thin pieces of sheet metal overlap was fastened with a rivet (PN 229 - Pl. 9: 85). ${ }^{22}$ Broad hoops, in this case to $21 \mathrm{~mm}$, were usually located on the lower parts, and thinner ones, in this case $10 \mathrm{~mm}$, on the upper parts of wooden buckets. The presumed wooden bucket, according to our modest finds and their

22 Fragment no. 1: preserved 1.: 140 mm; w.: 10 mm; th.: 2 mm; wt.: 12 g, dia. ca 160 mm; Fragment no. 2: 1.: $41 \mathrm{~mm}$, w.: 21-25 mm, th.: at the site of the overlapping of the hoop and the rivet $-7 \mathrm{~mm}$, at the site of one hoop - $2 \mathrm{~mm}$, wt.: $7 \mathrm{~g}$; dia. of the rivet $7 \mathrm{~mm}$. 
dimensions, certainly would have had at least two, and most probably three, hoops, as is usual for this type of object (Garam 1985, 372, fig. 225), although there could also have been more. According to an approximate calculation of the diameter of the thinner hoop, the presumed wooden bucket could have had in the middle section, and probably also in the upper section, a diameter of around $16 \mathrm{~cm}$, similar to examples cited by J. Zábojník, like an example with a clearly visible join of two ends of a hoop from one of the graves at the site of Devínska Nová Ves, where wooden buckets were present in large quantities (Zábojník 2009, 158, Pl. 2: 2/3/4; 168, Pl. 12), as well as in the settlement structures and features of the site of Přeclav-Pohansko, where several different dimensions were noted for this type of object used in everyday life (Vignatová 1980, 171, fig. 6). The upper hoop was half as wide as the fragment with the rivet, so it is possible that one more hoop with a width of ca. $15 \mathrm{~mm}$ would have been located in the middle, whose remains were not discovered in the archaeological excavation, just like the remains of the wood. A close analogy example can again be found at the cemetery at Brodski Drenovac, in female grave 16, where a wooden bucket of small dimensions with somewhat more robust hoops was placed above the head of the deceased woman (Vinski-Gasparini - Ercegović 1958, 147, Pl. XIV: 2; Pl. XXIV), which is dated to the beginning of the 9th century. However, a small wooden bucket was also found in grave 20 at Velika Gorica, a grave that was dated, like the other four discovered graves at that site, to the last decades of the 8th century, or around the year 800 (Vinski 1960, 50-51, 57, fig. 14) or the beginning of the 9th century (Katalog 2000, 108, II. 49 b). Even earlier was the child cremation grave 4 from the site of Vinkovci-Duga ul. 99, where the remains were found of the hoops of a wooden bucket with a width of $1 \mathrm{~cm}$ (20 pieces), together with other small objects and a vessel with an impressed small hollow on the lower surface of the base, probably buried/placed in the soil at some time from the end of the 7th to the middle of the 8th centuries (Sekelj Ivančan - Tkalčec 2006, 148-149, 162-163, Pl. 3; Pl. 7: 6, 7).

The same stratum also contained the earlier mentioned well-preserved small iron singlebladed knife with a thin handle (SJ 320: 1.: $81 \mathrm{~mm}$, w. blade: $13 \mathrm{~mm}$, w. tang: $5 \mathrm{~mm}$, th.: $2 \mathrm{~mm}$, wt.: $5 \mathrm{~g}$; Pl. 9: 84). The upper part of the blade is straight, at the end it gently descends into a rounded tip, while the tang for the handle extends from the upper half of the blade and is almost at the same level as the spine of the blade. According to its dimensions, it belongs to the class of smaller knife, such as are usually discovered in the settlements, but also the graves, of the early medieval period, but are poorly indicative in typological and chronological terms. The remaining iron objects from SJ 319 have undefined forms. One example could possibly represent the tang of a small knife with two small perforations that served to fastening the handle that had been made from some organic material, such as wood, that was not preserved (1.: $43 \mathrm{~mm}$, max. w.: $12 \mathrm{~mm}$, max. th.: $4 \mathrm{~mm}$, wt.: $3 \mathrm{~g}$; PN 104 - Pl. 9: 82). Considering the section, which shows a sharp point on one end, a second fragment could also have been a knife (1.: $49 \mathrm{~mm}$, w.: $9 \mathrm{~mm}$, th.: $2 \mathrm{~mm}$, wt.: 2 g; PN 103 - Pl. 9: 83). The above mentioned knives on the basis of the shape cannot serve for defining the period of their use, and even the small knife from the other early medieval feature found at this site has a different shape and it dated on the basis of other finds from the same context to the 8th and beginning of the 9th centuries (Sekelj Ivančan 2017b, 116-117, Pl. 4: 26).

\section{Concluding thoughts}

After it has been clearly established that remains existed within trench 8 and the larger excavated unit that can be attributed to two different periods, the Early and the High Middle Ages, it is also necessary to establish in what strata the medieval material was found. Stratum SJ 315 contained mixed finds of pottery with coarse and fine fabric, approximately in equal amounts, as this 
represents the uppermost stratum, noted at the beginning of excavation of the feature, while it was still not possible to distinguish differences in the colour and consistency of the soil. However, two strata located immediately beneath it, SJ 318 and SJ 320, display significant differences. In SJ 318 , where 236 fragments of pottery were discovered, those with a coarse fabric made on a slow potter's wheel predominated, while there were only 12 pieces of finer pottery. The situation is reversed in stratum SJ 320, where 231 fragments were found, 201 of them had a refined fabric, while only 30 had coarse fabric. The situation is similar in the other strata SJ 319 (238:68), SJ 324 (31:10), and SJ 336 (155:34+105:4), where the predominant proportions were greatly in favour of the fine fabric pottery made on a fast potter's wheel. Although minor deviations exist, ${ }^{23}$ according to the predominant pottery finds it can be established that at the spot where stratum SJ 318 extended, there had previously existed some small feature from the early medieval period that the following metal objects definitely belonged to: the bronze strap end and the trapezoidal buckle. This earlier feature extended in an E-W direction, possibly with a small extension/ deviation to the northeast, inasmuch as we also attribute to the early medieval period the area where remains were found of the hoops of a wooden bucket and a small iron knife.

Such a spatial image had been acquired in the undertaken geophysical investigations, which showed that anomalies appeared at places with thermoremanent types of magnetisation at archaeological remains related to metallurgical activities at this site (fig. 1a; Mušič et al. 2013). This small feature with an oval shape corresponds to finds of tiny fragments of pottery tuyeres/ nozzles, and considerable amounts of smelting debris, but also slag from smithing activities, so that it can, with a certain dose of reserve, considering the character of this site in the earlier historical periods and the quantity of waste at the site itself, be connected with activities related to the production and working of iron at this site. On the other hand, all the other strata (SJ $319,320,324,336)$ represent part of some structure, possibly a wooden building from the High Middle Ages or the transition from the Early to the High Middle Ages, which was built/positioned at the site of an earlier utilised area. This large oval structure was oriented NW-SE, and was characterised by fine fabric pottery, vessels made on a fast potter's wheel, fragments of whetstones, and metal fragments that could perhaps be remains of iron knives, one of which very probably had a handle of organic material. Although the sporadic appearance of fragments of pottery tuyeres and some fragments of iron-working discards were noted in the strata of the larger feature, it seems that the character of this feature (wooden building?) cannot be tied to the working of iron, and certainly not to forging, and probably also not to smelting (Table 1). The appearance of these finds can be related only to the fact that this was a site where smelting activities had been carried out in an earlier period, and that they were in fact secondary finds. A similar conclusion had been noted for the previously analysed and published archaeological units dated to the period of the High Middle Ages at this site, where such waste was not even present (Sekelj Ivančan 2018).

A separate small circular feature SJ 330, located just by the larger feature, can also be attributed to the same, later period, and the proportions in the representation of pottery were 20:4 in favour of the later examples, but its primary function was very difficult to determine, only the fact can be noted that there was a large quantity of soot in the upper parts of the fill.

Some of the questions related to the finds discussed here for which it will be difficult to find answers are related to the circumstance that the results of the radiocarbon analysis from the charcoal sample from SJ 320 gave a date in the early medieval period for this stratum (Cal AD 811 \pm 41 ), which the analysed predominantly pottery material from it does not confirm. Evidently in the reordering

23 Such deviations could have occurred as a result of disturbance of layers due to the multiple period settlement of this site, but also the manner of excavation, where it was not immediately noted that there were varied fills during uncovering of the feature. 
of the earlier layers in the form of the reuse of the same area, a contamination of the sample occurred, and during the excavations the charcoal sample taken and sent for analysis had arrived secondarily from an earlier feature into the later unit. The earlier feature truly did contain pottery material that with certainty can be classified to the period indicated by the C14 analysis. The period of utilisation of the stone quern will also remain undefined, as its fragments were discovered in all strata, and any connection will also remain unknown between it and the fragments of baking/ drying trays, also scattered throughout all the strata. Perhaps it is a positive circumstance that the largest amount of fragments of the baking/drying trays was found in the earlier feature that can be classified to the period in which such vessels were used (Bekić 2016b, 107-108), while future investigation will perhaps illuminate the occasional unclear factor.

Close analogies to the pottery finds that are classified here to the early medieval period can be found, in addition to the earlier mentioned area of the northern Drava basin micro-area in the vicinity of Torčec, in the broader Drava River region in Bekićs Drava-Mura-Sava 2a and 2 b groups (Bekić 2016b, 94-95). However, it is necessary to emphasise the site of Šarnjak near Šemovec, where detailed analysis of the material was undertaken that was supported by radiocarbon dates, primarily because of the fact that at the site an iron belt holder was discovered, whose source was probably identical to the source of our bronze strap end. ${ }^{24}$ On one side it was covered by a bronze engraved platelet decorated with a motif of S-shaped tendrils with pointed leaves, analogies for which can be found in the graves of the Avar cultural circle (like analogies to our strap end), on the basis of which L. Bekić approximately dated this somewhat simplified version of tendrils to the period between 710 and 760, the second third of the 8th century. On the basis of the analysis of the entirety of the material, however, the author nonetheless dated the excavated features and structures of this settlement somewhat later, to the very late 8th and the very beginning of the 9th centuries, while the appearance of the belt holder as a separate element of a belt set was interpreted as a objects preserved in use for a lengthy time (Bekić 2016a, 228-230, 232; Pl. 5: 13; 2016b, 128-129, fig. 85). Our earlier finds from the feature extending E-W (lower) can be attributed to the second half of the 8th century or the late 8th and early 9 th centuries, both pottery and metal items that can be attributed to an "Avar provenience"/"Avar source". Such individual objects that can be connected to the material culture of the Avars (and Slavs), most of them parts of fragmented belt sets but also other elements, are not unknown in the pre-Alpine region in the period of the second half of the $8^{\text {th }}$ century and are present at a dozen archaeological sites in Slovenia (Karo - Knific - Lubšina-Tušek 2011, 133, fig. 1). Slovenian individual settlement finds are interpreted variously depending on the type of sites at which they were found, so that objects discovered at elevated fortified sites are considered tied to loot from the Frankish-Avaric conflicts at the transition from the 8th to the 9th centuries, while those that come from lowland settlements, such as our strap end, or rather our site, would reflect the Avaro-Slavic relations on the edges of the Pannonian Plain (Karo - Knific - Lubšina-Tušek 2011, 144), and this should also apply to this part of our site at Sušine dated to the same period.

It has been shown that sites that were inhabited during the early medieval period (7th and 8th centuries) often also had a later horizon of settlement, as was recognised at Sušine, as well as other examples of excavated and published settlements from the surrounding Drava River region

24 The discovery of several fragments of glass, probably from earlier periods, represents yet another similarity between Šarnjak and Sušine, where a fragment of the rim of a small glass vessel was found, which at our site comes from the contacts of the ploughed layer with the next to the last layer inside trench 8 , but beyond the archaeological features (Pl. 9: 87). This was transparent glass with many tiny and one larger "bubble", a structure indicating that it was a Roman fragment. Fragments of Roman glass were also found at the early medieval site of Prečno pole in Torčec (Sekelj Ivančan 2010, 150-151, 228, Pl. 8: 45). 
(Sekelj Ivančan 2010, 17-25), the dates of which are supported by radiocarbon dating. Other than the above-mentioned Prečno pole at Torčec (Sekelj Ivančan 2010) and Šarnjak near Šemovec (Bekić 2016a), citing only a few examples, through use of the $\mathrm{C} 14$ method the finds were more precisely dated from the site of Stara ves near Nedelišće with remains from the first half of the 7 th and again later from the second half of the 11th century (Bekic 2006, 218), as well as those from the site of Jakopovec-Blizna with remains from the 8th and 9th centuries and later from the High Middle Ages (Bekić 2006, 125, Pl. 28: 9-10), and Brezje 1 near Varaždin with two settlement horizons the 8th - 9th and the 11th - 12th centuries (Bekić 2006, 289-291; 2009) from the upper Drava River basin region, but similar sites are also known further east, downriver on the Drava, such as the site of Virovitica-Đota, also with two layers of settlement (the 7th - 8th and the 10th 11th centuries; Sekelj Ivančan - Tkalčec 2008). ${ }^{25}$ All of these sites were slightly elevated in their individual landscapes and were hence especially suitable for settlement. The choices for locations for settlement in the lowlands along the Drava River certainly would have required a nearby source of water, but also protection from penetration by flood waters from the nearby major river, hence the population throughout all (pre)historical periods, including the Middle Ages, utilised slightly elevated terrain and deposited sand crests for the location of their settlements, as was the case for all the above cited examples. Hence it is not unusual that at Sušine, on a slightly elevated sand bank in an otherwise lowland environment, the same position contained remains from the Early Middle Ages (second half of the 8th and beginning of the 9th centuries), and subsequently remains from the High Middle Ages. It should be noted that in the part of Sušine excavated to the present certain differences were noted in the pottery material of the High Middle Ages in terms of the forms and decoration of ordinary cooking pots utilised for everyday use. They indicate the chronological definition of the context from which they came: the finds described here were slightly earlier (11th and beginning of the 12th centuries) than those that came from the archaeological features in the southern part of the site that is dated from the end of the 11th to the beginning of the 13th centuries (Sekelj Ivančan 2018). On the basis of the available material, the lack of material traces from the period at the end of the 9th and the 10th centuries, means that it cannot be stated at present with any degree of security that an uninterrupted continuity of settlement existed at this site throughout several medieval centuries.

To what extent, on the other hand, was the settlement of this location at the site of Sušine caused by economic activities related to the exploitation of iron ore, at the present level of knowledge this can perhaps most positively be concluded for the earlier archaeological periods (the Early Iron Age?, Late Antiquity), and also most probably for the horizon of settlement in the early medieval period. No reliable data is yet available for the later medieval period, but the possibility should be noted that future archaeological excavation might change this image. More extensive archaeological excavations, which would also establish the total number of settlement and production structures and features in all archaeological periods of the inhabited positions at Sušine, as well as the spectrum of all kinds of archaeological finds from the structures and features, would also enable answers for further considerations about this site, and the examination of potential reasons for the existence of this site in various periods at this same position. Related to this, if the idea about a lack of continuity in economic activities related to the processing of iron ore between the Early and High Middle Ages in fact remained unchanged, a path would open for totally new investigations that could be oriented to the question of the exhaustion of natural resources - iron

${ }_{25}$ An expanded list of early medieval rural sites where archaeological excavation have confirmed existence throughout several centuries of the Middle Ages from the region of northern Croatia can be found at the link (http://www.iarh.hr/media/arhiva/Tablica\%201_Popis_Naselja.pdf), including available literature (http://www.iarh.hr/media/arhiva/naseljaliteratura.pdf; 22 May 2018). 
ores - specifically at this site at the end of the early medieval period. The impetus for again raising this settlement in the 11th century at the same position, after a pause of nearly two centuries, should in this case be sought in other reasons. All of this, of course, is only relevant if more extensive investigations would confirm the present knowledge about a lack of settlement of Sušine after the beginning of the 9th century and throughout the entire 10th century.

\section{Bibliography}

Bekić, Luka. 2006. Zaštitna arheologija u okolici Varaždina. Arheološka istraživanja na autocesti Zagreb - Goričan i njezinim prilaznim cestama. Zagreb.

Bekić, Luka. 2009. Ranosrednjovjekovno naselje Varaždin - Brezje. In Tomičić, Željko - Uglešić, Ante (eds.). Zbornik o Luji Marunu, Zbornik radova sa Znanstvenog skupa o fra Luji Marunu u povodu 150. obljetnice rođenja (1857.-2007.), Skradin-Knin, 7.-8. prosinca 2007.g., ŠibenikZadar-Zagreb, 205-219.

Bekić, Luka. 2010. Srednjovjekovna jama K 12 s nalazišta Jalkovec-Police kod Varaždina. In Archaeologia Adriatica IV, 227-241.

Bekić, Luka. 2012. Keramika praškog tipa u Hrvatskoj. In Šeparović, Tomislav (ed.). Zbornik radova sa Znanstvenog skupa «Dani Stjepana Gunjače 2». Hrvatska srednjovjekovna povijesno-arheološka baština. Međunarodne teme, Split, 18.-21. listopada 2011.g., Split, 21-35.

Bekić, Luka. 2016a. Nalazi 8. i 9. stoljeća sa Šarnjaka kod Šemovca / Finds from the 8th and 9th centuries at Šarnjak near Šemovec. In Vjesnik Arheološkog muzeja u Zagrebu 3. s., XLIX, 219-248.

Bekić, Luka. 2016b. Rani srednji vijek između Panonije i Jadrana. Ranoslavenski keramički i ostali arheološki nalazi od 6. do 8. stoljeća, Monografije i katalozi 27, Arheološki muzej Istre. Pula.

Garam, Éva. 1987. Pferdegräber der awarenzeitlichen Gräberfeldes in Tiszafüred. Angaben der spätawarenzeitlichen Pferdebestatungen. In Alba Regia 23, 65-125.

Garam, Éva. 1995. Das awarenzeitliche Gräberfeld von Tiszafüred. Cemeteries of the Avar Period (567-829) in Hungary. Vol. 3. Budapest.

Garam, Éva - Kovrig, Ilona, Szabó, János Gyözö - Török, Gyula. 1975. Avar Finds in the Hungarian National Museum. Cemeteries of the Avar Period /567-829/ in Hungary. Vol. 1, Budapest.

Karo, Špela - Knific, Timotej - Lubština-Tušek, Marija. 2011. Predmeti avarskega izvora $\mathrm{z}$ arheoloških najdišč v Sloveniji. In Vjesnik Arheološkog muzeja u Zagrebu 3. s., XLIV, 131-159.

Katalog. 2000. Milošević, Ante (ed.). Hrvati i Karolinzi/Croats and Carolingians, exhibition catalogue, Muzej hrvatskih arheoloških spomenika/Museum of Croatian Archaeological Monuments. Split.

Měchurová, Zdeňka. 1983. Třmeny a jiné součásti sedla z časné středověkého období [Die Steigbügel und andere Sattelsbestandteile aus dem Frühmittelalter]. In Časopis Moravského Muzea v Brně. Vědy společenské 68, 61-89.

Mušič, Branko - Medarič, Igor - Mori, Matjaž - Nas, Eline. 2013. Izvješće o geofizičkim istraživanjima na arheološkom lokalitetu Virje - Volarski breg/Sušine, Hrvatska, Maribor 2013. ARHINDOKS of the Institute of Archaeology (manuscript).

Pleterski, Andrej. 2011. Das Verhältnis zwischen dem Volumen und dem Durchmesser eines Topfers. In Archaeologica Adriatica 3 (2009), 323-333.

Rapan Papeša, Anita - Šmalcelj Novaković, Pia. 2016. Kasnoavarodobno groblje na Gradini u Otoku, exhibition catalogue. Vinkovci. 
Sekelj Ivančan, Tajana. 2000. Slučajni nalaz ognjišta na lokalitetu Borovljani-Srednje brdo kraj Koprivnice i slični srednjovjekovni nalazi evidentirani na području sjeverne Hrvatske. In Prilozi Instituta za arheologiju 17, 67-88.

Sekelj Ivančan, Tajana. 2010. Podravina u ranom srednjem vijeku, Rezultati arheoloških istraživanja ranosrednjovjekovnih nalazišta u Torčecu, Monographiae Instituti Archaeologici 2. Zagreb.

Sekelj Ivančan, Tajana. 2017a. Ranosrednjovjekovno naselje na Volarskom bregu u Virju. In Zbornik Instituta za arheologiju 6, 111-131.

Sekelj Ivančan, Tajana. 2017b. Ranosrednjovjekovni objekt na Sušinama u Virju. In Cris, Časopis Povijesnog društva Križevci XIX., no. 1, 115-128.

Sekelj Ivančan, Tajana. 2018. Arheološki tragovi naseljenosti Sušina u Virju tijekom razvijenoga srednjeg vijeka. In Zbornik Instituta za arheologiju (in press).

Sekelj Ivančan, Tajana - Botić, Katarina - Culiberg, Metka. 2018. Biljni pokrov Đurđevačkih pijeska i okolice - arheološka perspektiva: studija slučaja Virje-Volarski breg, HAZU Križevci (in press).

Sekelj Ivančan, Tajana - Mušič, Branko. 2014. Geofizička i arheološka istraživanja na nalazištu Virje - talionička radionica iz vremena kasne antike i ranog srednjeg vijeka. In Starohrvatska prosvjeta III. ser., Vol. 41, 177-184.

Sekelj Ivančan, Tajana - Karavidović, Tena. 2016. Tkalački stan iz Virja. In Prilozi Instituta za arheologiju 33, 171-235.

Sekelj Ivančan, Tajana - Tkalčec, Tatjana. 2006. Slavensko paljevinsko groblje na položaju Duga ulica 99 u Vinkovcima. In Prilozi Instituta za arheologiju 23, 141-212.

Sekelj Ivančan, Tajana - Tkalčec, Tatjana. 2008. Medieval settlements in the Virovitica Region of the Drava River Basin in the period from the 7th to the 11th centuries. In Guštin, Mitja (ed.). Srednji vek. Mittelalter, Narodni muzej Slovenije, Ljubljana, Inštitut za dediščino Sredozemlja, Znanstveno-raziskovalno središče Koper, Univerza na Primorskem, Ljubljana, 113-128.

Stadler, Peter. 1991. Argumente für die Echtheit des „Avar Treasure. In Mitteilungen der Anthropologischen Gesellschaft in Wien 118/119 (1988/89), 193-217.

Szenthe, Gergely. 2013, Vegetal ornaments in the Late Avar decorative art. In Dissertationes Archaeologicae, Ser. 3. No. 1, 303-320.

Vignatová, Jana. 1980. Součásti jezdecké výstroje z nálezů na Pohansku u Břeclavě. In Sborník prací Filozofické fakulty brněnské univerzity. Řada archeologicko-klasická E25, 161-198.

Vinski, Zdenko. 1960. Ranosrednjovjekovni arheološki nalazi u Zagrebu i njegovoj okolici. In Iz starog i novog Zagreba II, 47-65.

Vinski-Gasparini, Ksenija - Ercegović, Slavica. 1958. Ranosrednjovjekovno groblje u Brodskom Drenovcu. In Vjesnik Arheološkog muzeja u Zagrebu, 3. ser. Vol. I, 129-161, Pl. I.-XXVII.

Zábojník, Jozef. 2009. Slovensko a Avarský kaganát. Studia Archaeologica et Medievalia. Vol. IX. Bratislava.

\section{Abbreviations}

cf. - to compare somebody/something to somebody/something

$\mathrm{cm}$ - centimetre

dia. - diameter

g- gramme

ht. - height

$\mathrm{kg}$ - kilogramme

1. - length 


$$
\begin{aligned}
& \text { max. - maximum } \\
& \text { mm - millimetre } \\
& \text { no. - number } \\
& \text { nos. - numbers } \\
& \text { SJ - stratigraphic unit } \\
& \text { th. - thickness } \\
& \text { w. - width } \\
& \text { wt. - weight }
\end{aligned}
$$

SUMMARY: SETTLEMENT CONTINUITY AT SUŠINE SITE NEAR VIRJE (NORTH CROATIA) THROUGHOUT THE MIDDLE AGES. The work discusses archaeological material from two archaeological units excavated within trench S-8 at the site of VirjeSušine (North Croatia). On the basis of detailed analysis of fragments of pottery vessels and several metal objects, two horizons of settlement were recognised at this site during the Middle Ages.

The basic characteristics of the earlier horizon consist of coarse pots made on a slow potter's wheel, the edges with simple molding and a combed decoration of irregular notches or wavy lines, which on the basis of analogies from the surrounding area can be assigned to the early medieval period. They are joined by a bronze single-part cast belt strap end, an iron trapezoidal belt buckle, and parts of the hoops of a wooden bucket and a small knife, which can be dated to the second half of the 8th and beginning of the 9th centuries.

The later settlement horizon at this site was characterised by pots with a refined fabric made on the fast potter's wheel, with more developed edges and more regular combed wavy lines, along with the appearance of other decorative motifs, such as single wavy lines, bunches of horizontal lines, and various combinations. On the basis of the characteristics of this pottery, it can be classified to the High Middle Ages, more precisely to the period of the entire 11 th century and the beginning of the 12th century.

Slight elevations, such as that where the Sušine site is located, located in otherwise low-lying environment of the Drava River lowlands, were suitable for long-term retention of the population at certain places. An essential role in the choice of a dwelling location, particularly in the example of the Virje sites, was certainly held by the smelting activities that took place in the region in the Early Middle Ages, as was shown by the archaeological excavations.

dr. sc. Tajana Sekelj Ivančan

Institute of Archaeology

Ulica Ljudevita Gaja 32

10000 Zagreb

Croatia

tsivancan@iarh.hr

dr. sc. Tatjana Tkalčec

Institute of Archaeology

Ulica Ljudevita Gaja 32

10000 Zagreb

Croatia

ttkalcec@iarh.hr 


\section{Appendix / Prílohy}

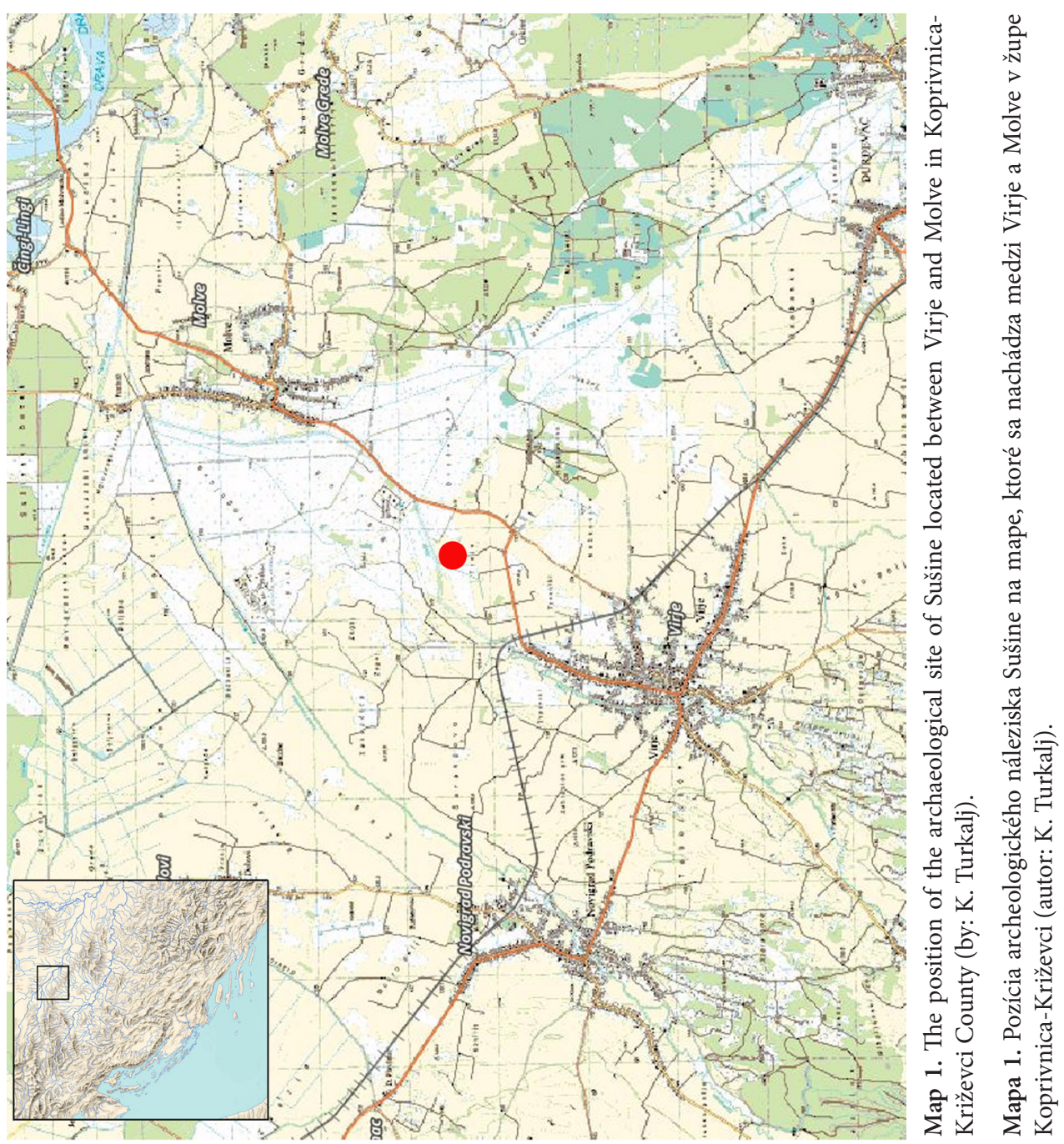




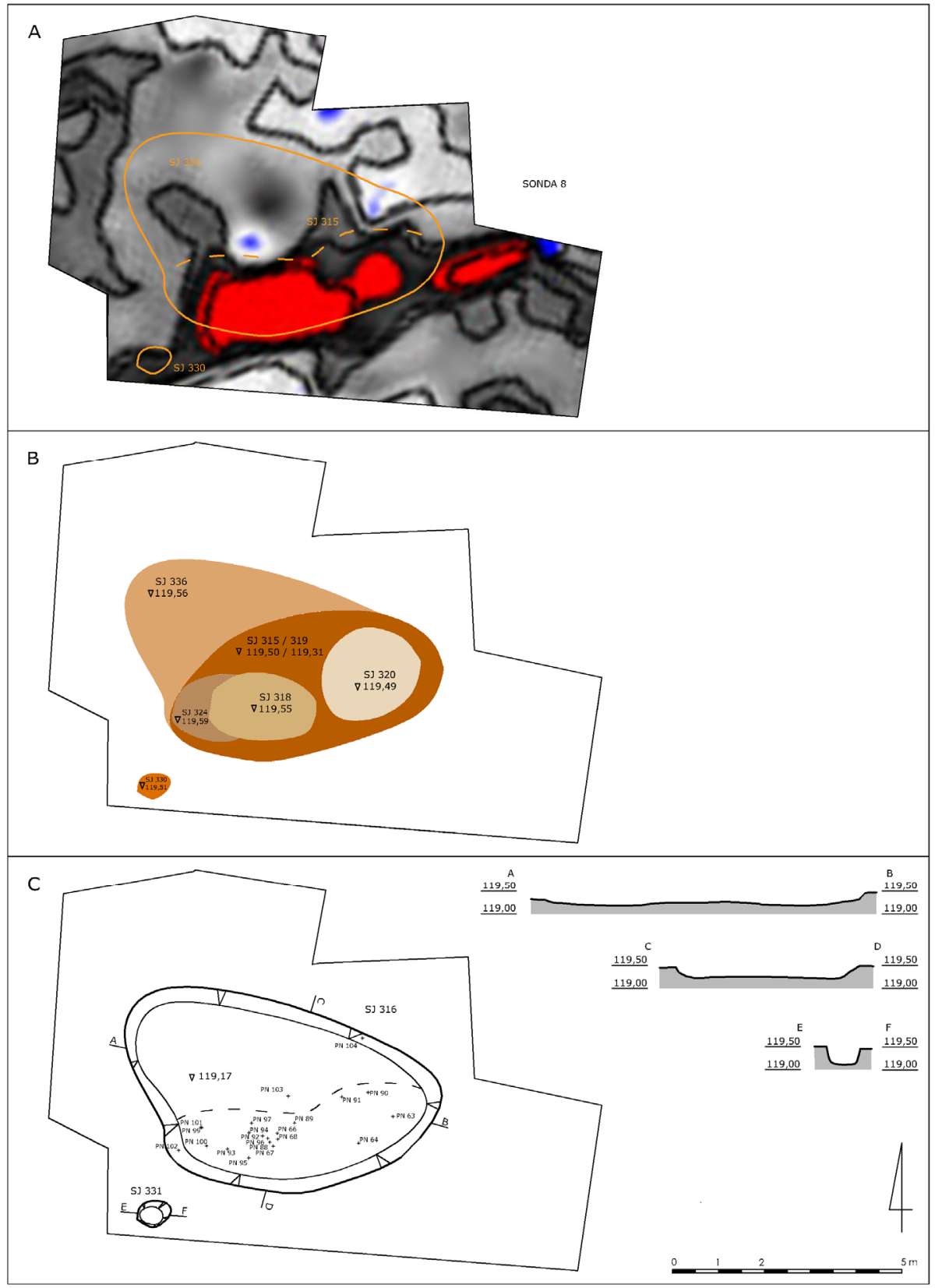

Fig. 1. Virje-Sušine. Plan of the noted and excavated fills and pits with cross-sections in trench S-8: a) results of geophysical investigation: anomalies in the framework of the surface of trench 8 (Mušič et al 2013); b) all strata; c) pit SJ 316, 390 (drawing: K. Jelinčić Vučković).

Obr. 1. Virje-Sušine. Plán registrovaných i skúmaných výplní a jám s prierezmi v sonde S-8: a) výsledky geofyzikálneho bádania: anomálie v rámci povrchu sondy 8 (Mušič et al 2013); b) všetky vrstvy; c) jama stratigrafickej jednotky SJ 316, 390 (kresba: K. Jelinčić Vučković). 


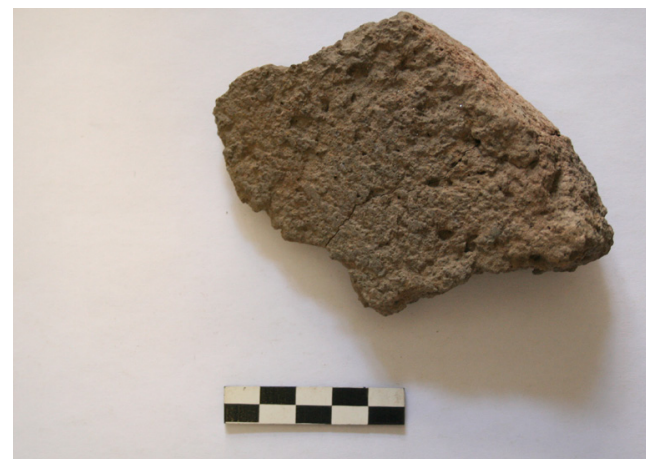

Fig. 2. Virje-Sušine. A fragment of a stone quern from SJ 315 (photo: T. Sekelj Ivančan).

Obr. 2. Virje-Sušine. Fragment kamenného žarnova zo stratigrafickej jednotky SJ 315 (fotografia: T. Sekelj Ivančan).

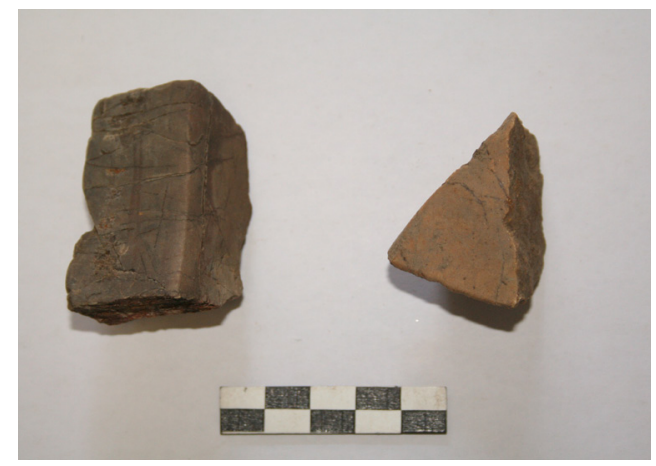

Fig. 3. Virje-Sušine. Fragments of whetstones: a) SJ 315: grey; b) SJ 001/336: ochre (photo: T. Sekelj Ivančan).

Obr. 3. Virje-Sušine. Fragmenty brúsikov: a) stratigrafická jednotka SJ 315: sivý; b) stratigrafická jednotka SJ 001/336: okrový (fotografia: T. Sekelj Ivančan).

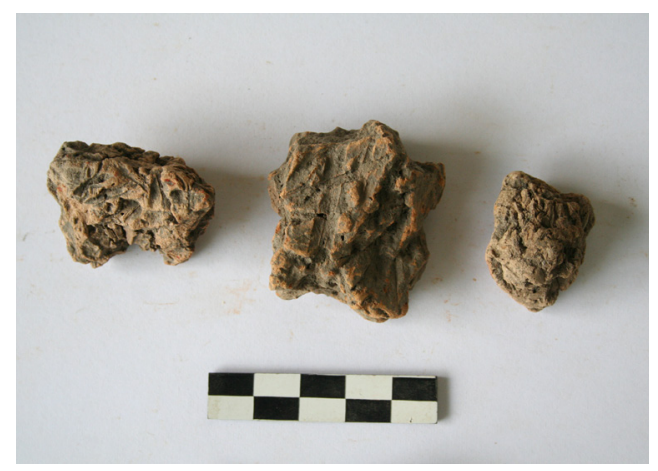

Fig. 4. Virje-Sušine. Fragments of baking or drying trays from stratum SJ 315 (photo: T. Sekelj Ivančan).

Obr. 4. Virje-Sušine. Fragmenty keramických tácok na pečenie a sušenie z vrstvy SJ 315 (fotografia: T. Sekelj Ivančan). 


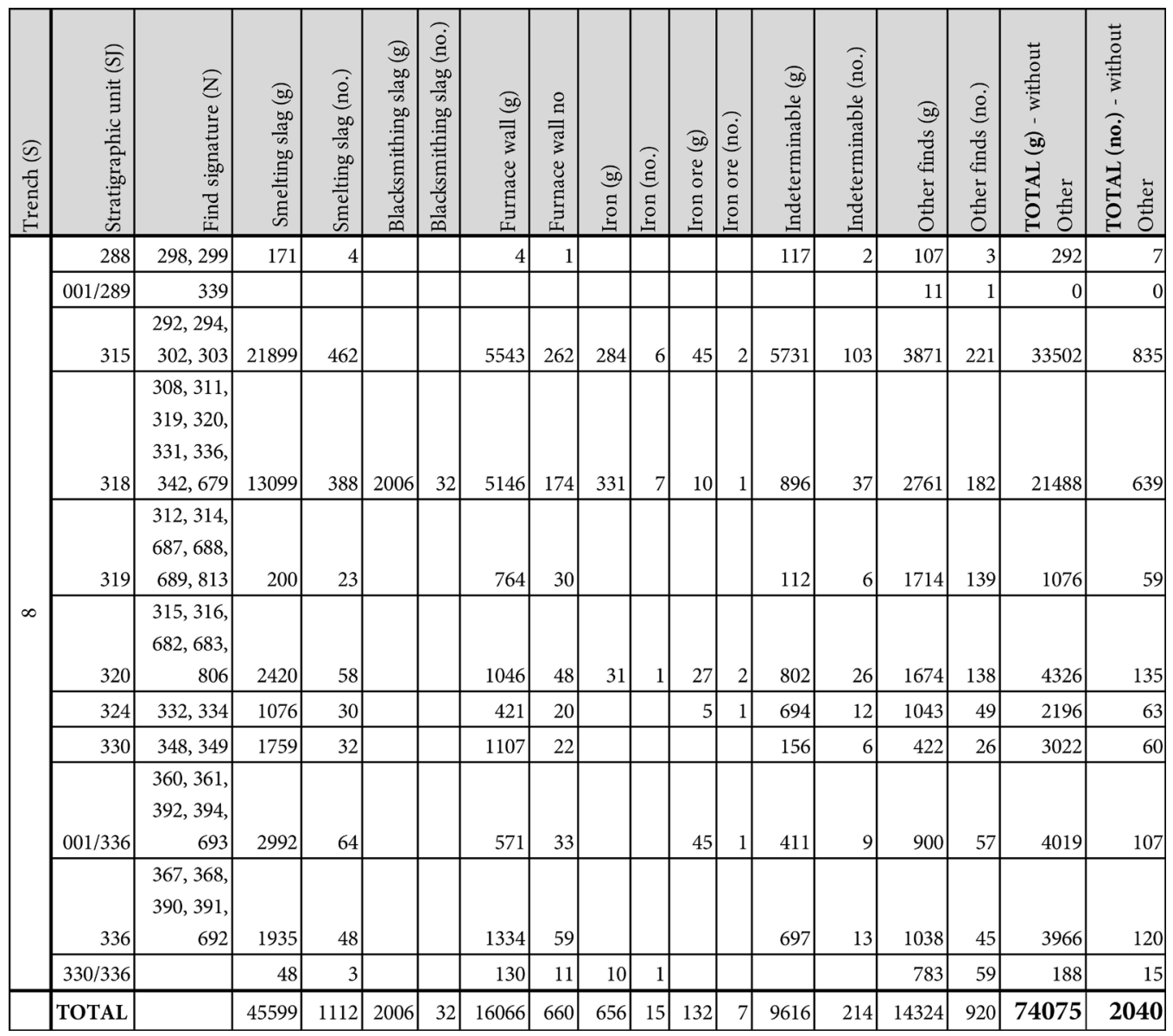

Table 1. The basic results of macroscopic analysis of the slag and daub from trench 8 at Virje-Sušine site.

Tabela 1. Základné výsledky makroskopickej analýzy trosky a mazanice zo sondy 8 na nálezisku Virje-Sušine. 


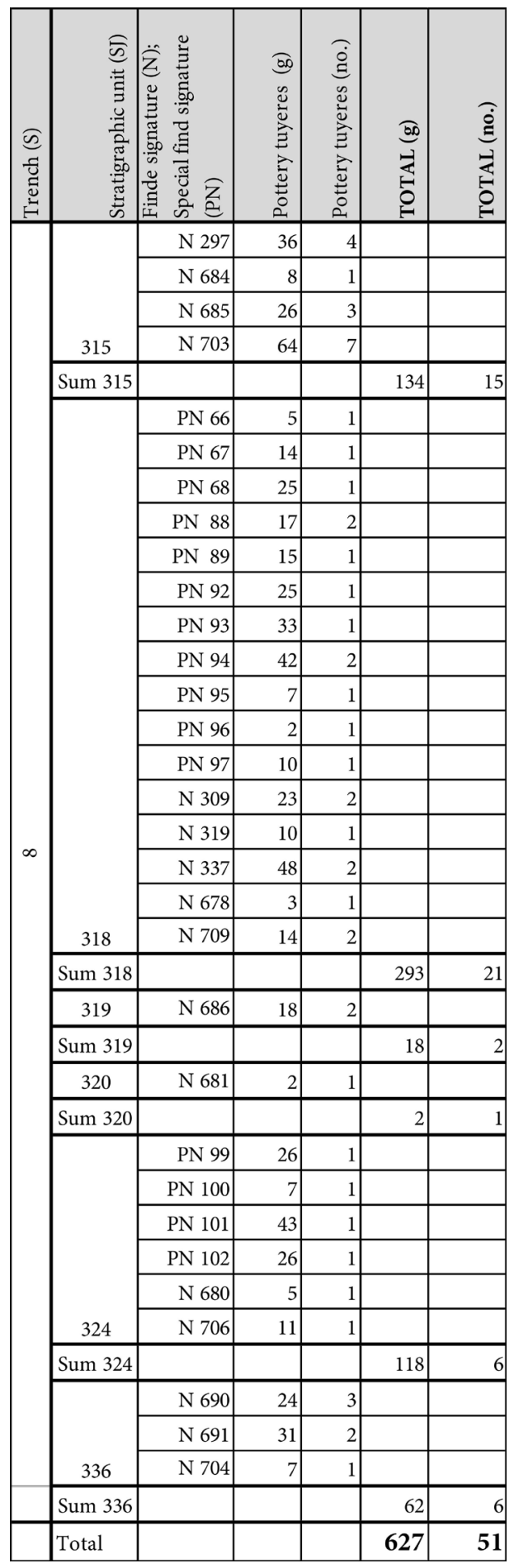

Table 2. Fragments of pottery tuyeres from trench 8 at Virje-Sušine site.

Tabela 2. Fragmety keramických dýz zo sondy 8 na nálezisku Virje-Sušine. 


\begin{tabular}{|c|c|c|c|c|}
\hline $\begin{array}{l}\text { Trench (S); } \\
\text { Context (SJ) }\end{array}$ & $\begin{array}{c}\text { Find } \\
\text { signature }(\mathrm{N})\end{array}$ & $\begin{array}{l}\text { Number } \\
\text { of fragments }\end{array}$ & $\begin{array}{l}\text { Weight of frag- } \\
\text { ments (g) }\end{array}$ & Note \\
\hline S-7; SJ 001/288 & N 768 & 5 & 72 & \\
\hline S-7; SJ 303 & N 769 & 2 & 33 & \\
\hline S-7; SJ 317 & N 770 & 5 & 54 & \\
\hline S-7; SJ 321 & N 771 & 5 & 53 & \\
\hline S-7; SJ 001/323 & N 772 & 1 & 12 & \\
\hline S-7; SJ 340 & N 773 & 6 & 54 & \\
\hline S-7; SJ 351 & N 774 & 4 & 40 & \\
\hline S-7; SJ 353 & N 775 & 8 & 62 & \\
\hline Total S-7 & & 36 & 380 & \\
\hline S-8; SJ 315 & N 776 & 49 & 657 & $\begin{array}{l}8 \text { fragments with polished } \\
\text { surface }\end{array}$ \\
\hline S-8; SJ 318 & N 777 & 72 & 1334 & $\begin{array}{l}11 \text { fragments with polished } \\
\text { surface, } 6 \text { of which are angular }\end{array}$ \\
\hline S-8; SJ 319 & N 778 & 22 & 666 & 4 fragments of rims \\
\hline S-8; SJ 320 & N 779 & 16 & 342 & $\begin{array}{l}1 \text { fragment with polished } \\
\text { surface }\end{array}$ \\
\hline S-8; SJ 324 & N 780 & 6 & 59 & $\begin{array}{l}1 \text { fragment with polished } \\
\text { surface }\end{array}$ \\
\hline S-8; SJ 330 & N 781 & 10 & 267 & \\
\hline S-8; SJ 001/336 & N 782 & 13 & 156 & \\
\hline S-8; SJ 336 & N 783 & 19 & 499 & $\begin{array}{l}1 \text { fragment with polished } \\
\text { surface }\end{array}$ \\
\hline Total S-8 & & 207 & 3980 & \\
\hline S-10b; SJ 001/002 & N 784 & 2 & 221 & $\begin{array}{l}1 \text { fragment with polished } \\
\text { surface }\end{array}$ \\
\hline S-10b; SJ 430 & N 785 & 1 & 50 & \\
\hline S-10b; SJ 436 & N 786 & 8 & 870 & $\begin{array}{l}4 \text { larger fragments, } 1 \text { of which } \\
\text { is angular }\end{array}$ \\
\hline Total S-10 & & 11 & 1141 & \\
\hline S-11; SJ 452 & N 787 & 3 & 37 & \\
\hline Total S-11 & & 3 & 37 & \\
\hline Total all trenches & 20 & 257 & 5538 & 28 \\
\hline
\end{tabular}

Table 3. Basic data about fragments of baking/drying trays discovered during excavation of the site of Sušine near Virje.

Tabela 3. Základné dáta týkajúce sa fragmentov tácok na pečenie/sušenie, ktoré sa našli počas výskumu náleziska Sušine blízko Virje. 


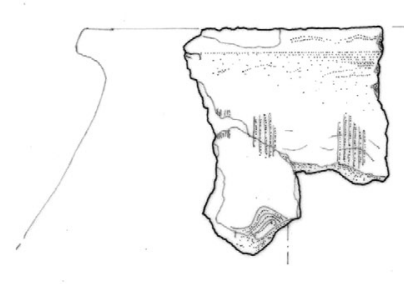

1
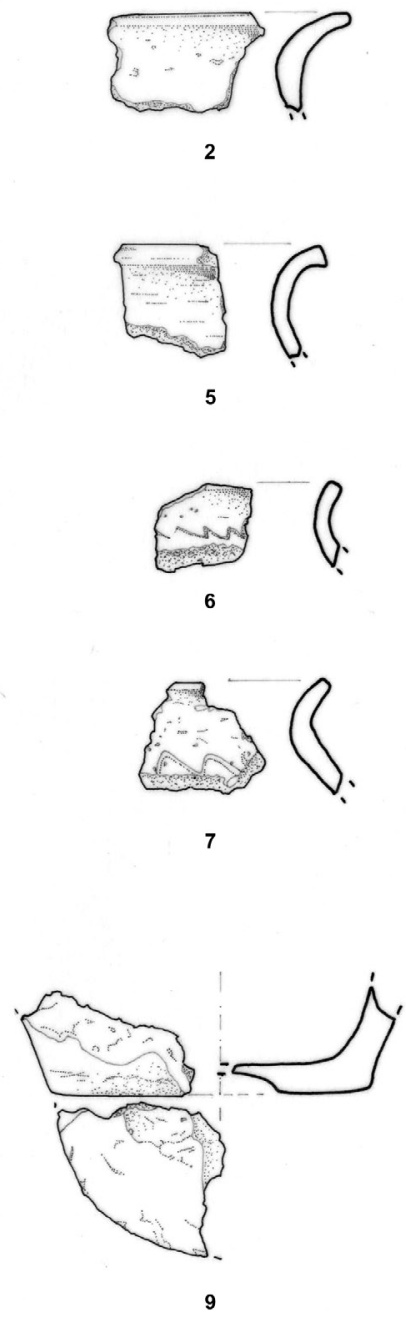

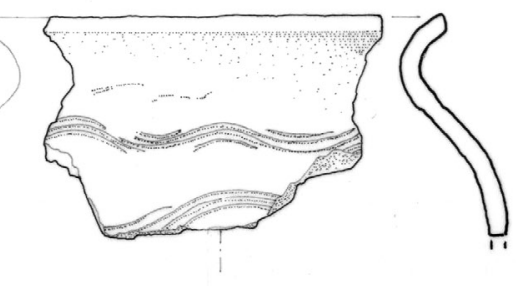

3
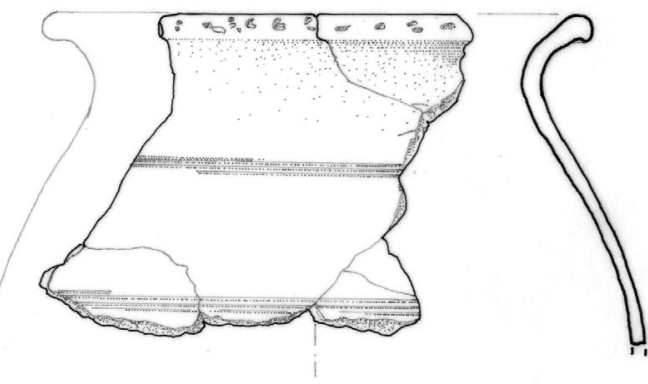

4

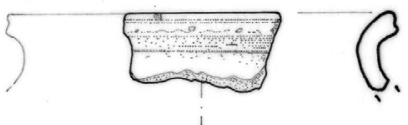

8

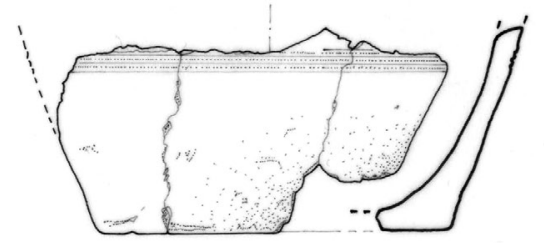

10

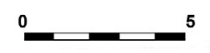

Pl. 1. Virje-Sušine. 1-10: Fragments of pottery vessels from SJ 315.

Tab. 1. Virje-Sušine. 1-10: Fragmenty keramických nádob zo stratigrafickej jednotky SJ 315. 


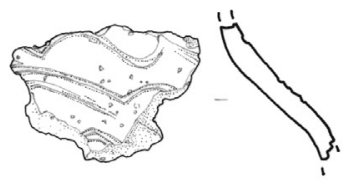

11

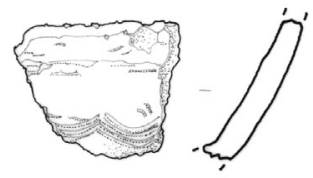

13

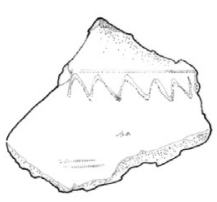

15

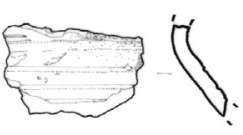

17

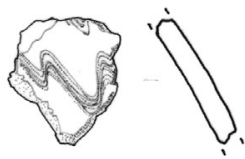

18
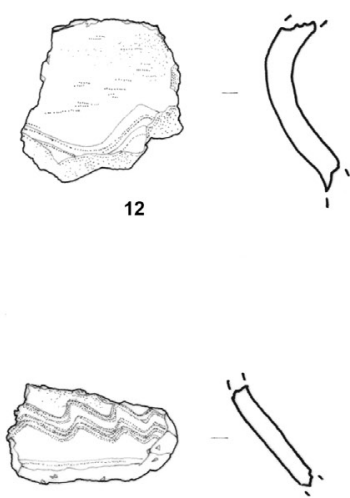

14

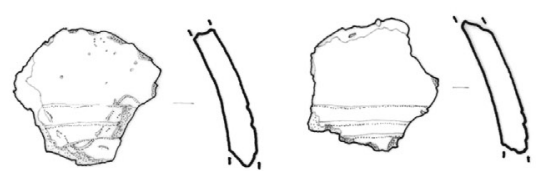

a

16

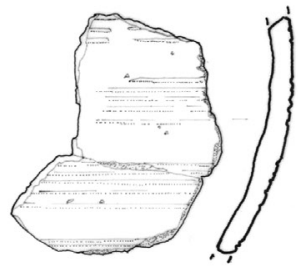

19

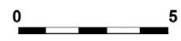

Pl. 2. Virje-Sušine. 11-19: fragments of pottery vessels from SJ 315.

Tab. 2. Virje-Sušine. 11-19: fragmenty keramických nádob zo stratigrafickej jednotky SJ 315. 

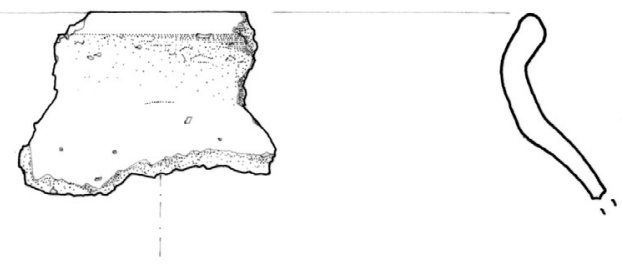

20

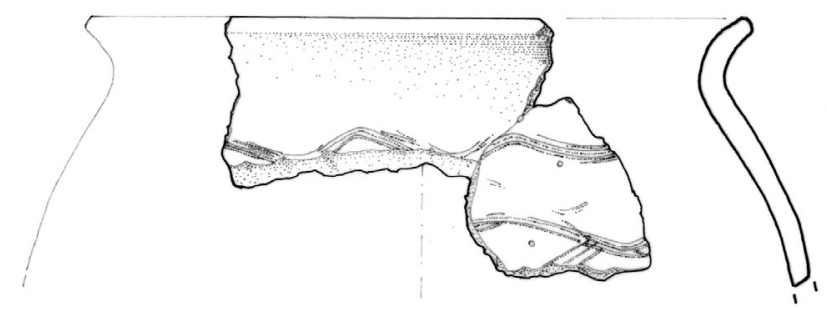

21

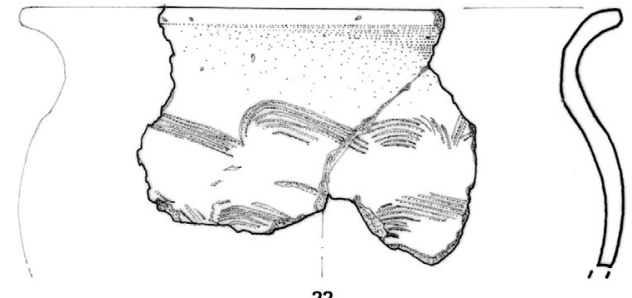

22

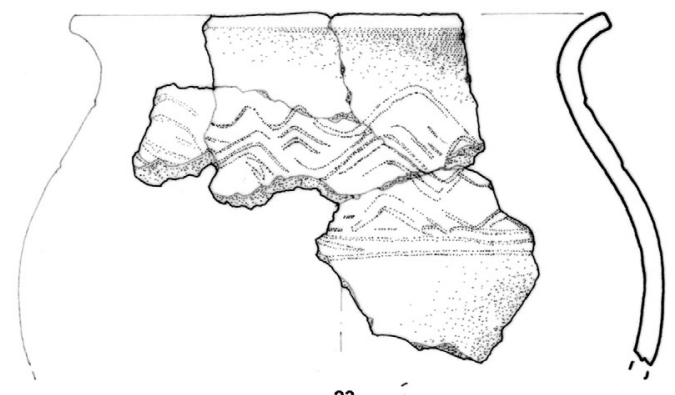

23

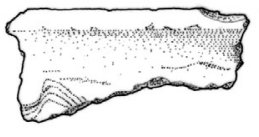

24

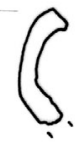

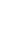

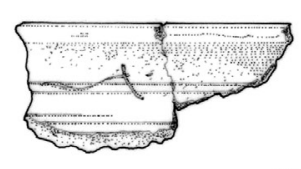

25

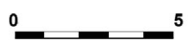

P1. 3. Virje-Sušine. 20-25: fragments of pottery vessels from SJ 318.

Tab. 3. Virje-Sušine. 20-25: fragmenty keramických nádob zo stratigrafickej jednotky SJ 318. 


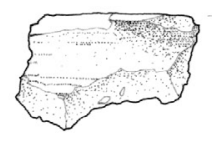

26

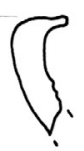

.

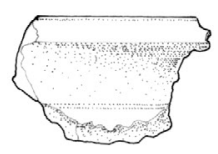

27

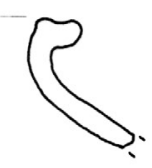

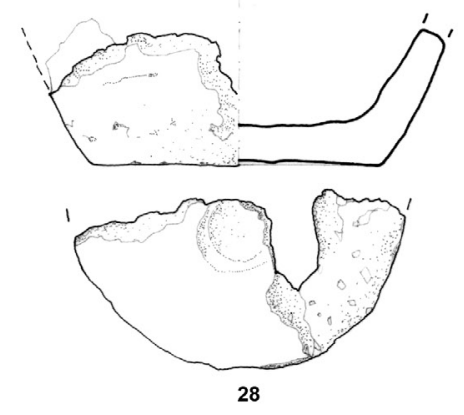

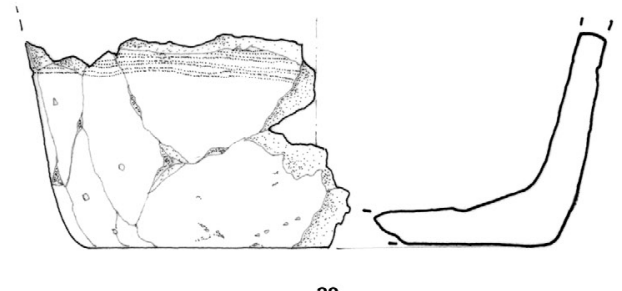

29

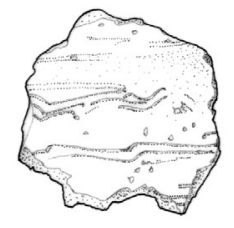

30

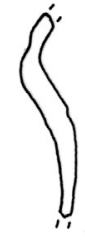

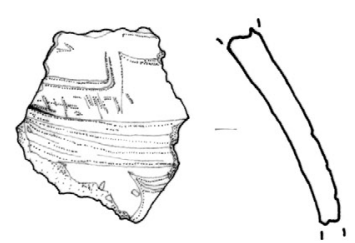

32

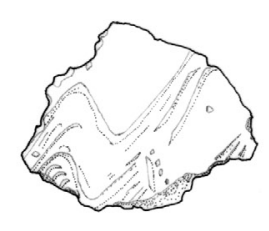

a
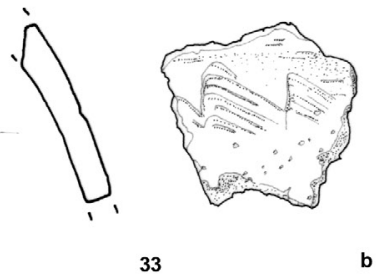

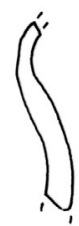

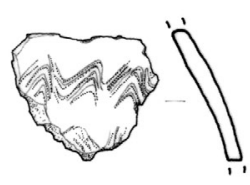

31

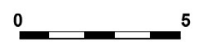

Pl. 4. Virje-Sušine. 26-33: fragments of pottery vessels from SJ 318.

Tab. 4. Virje-Sušine. 26-33: fragmenty keramických nádob zo stratigrafickej jednotky SJ 318. 

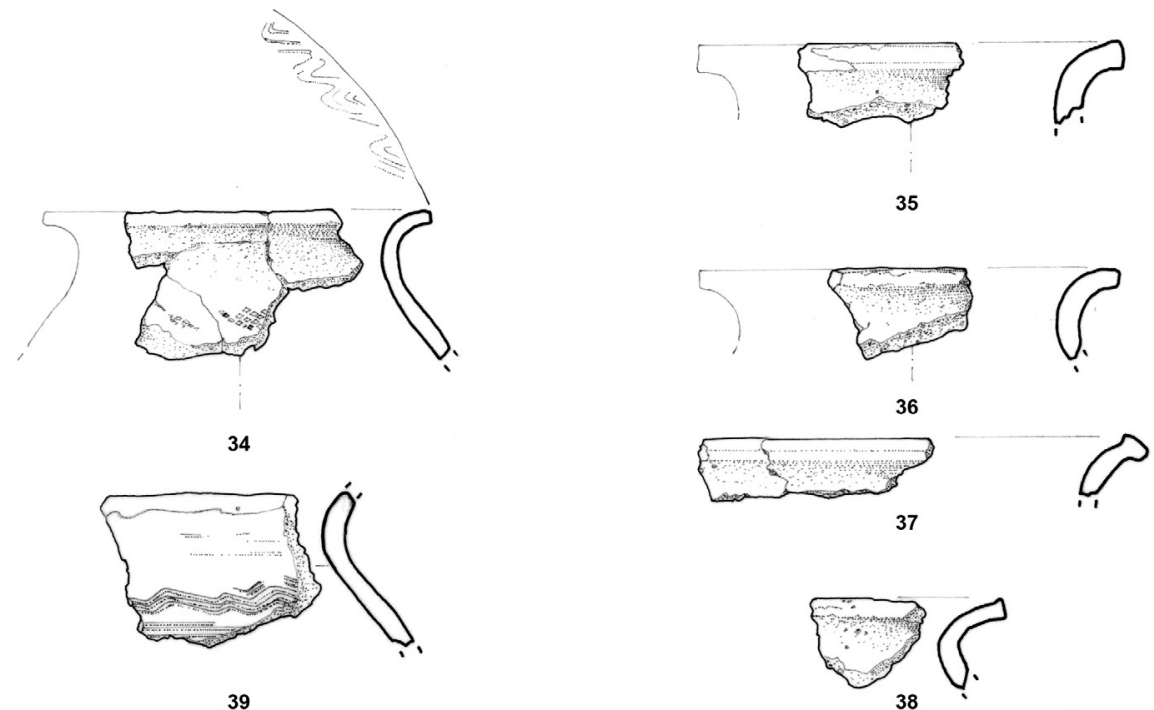

35
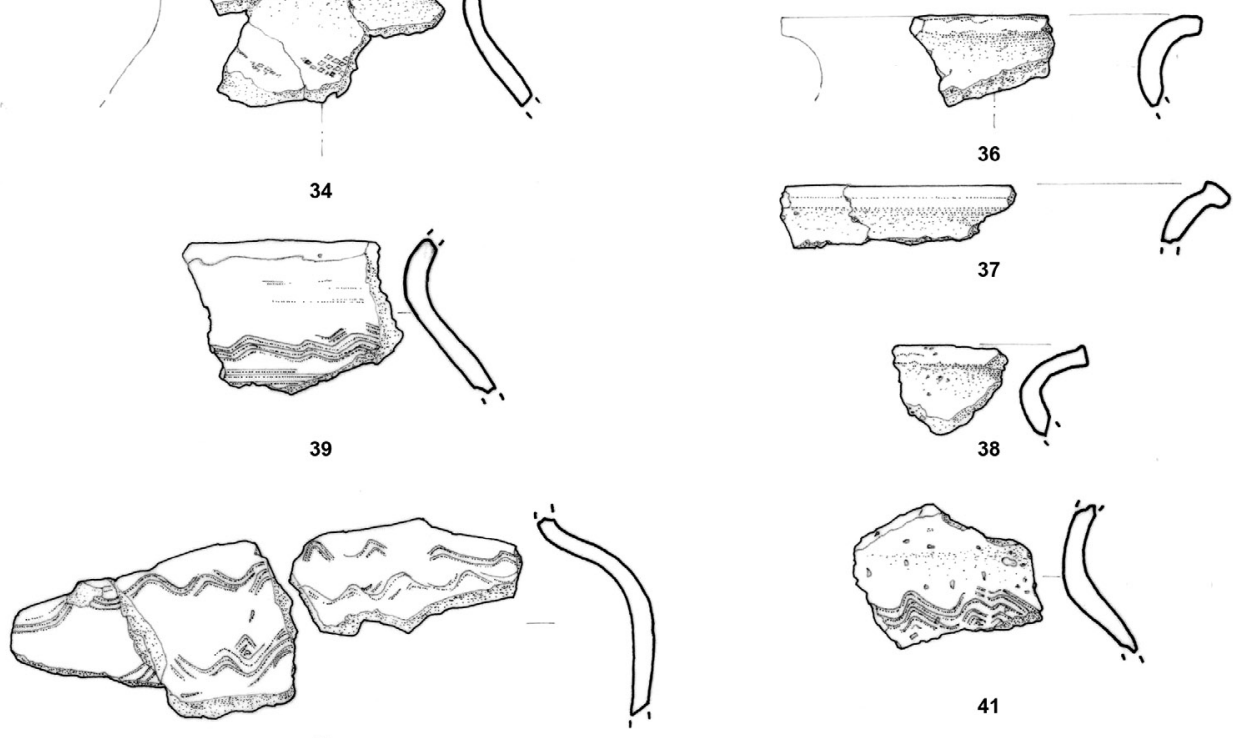

41

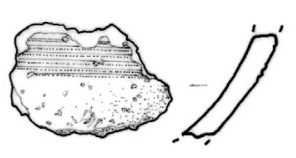

42
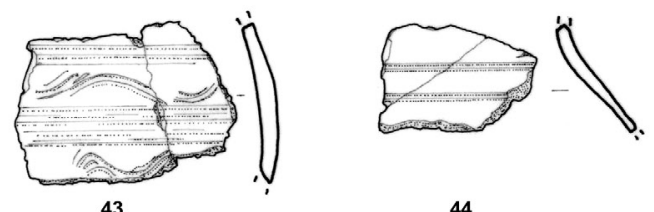

44

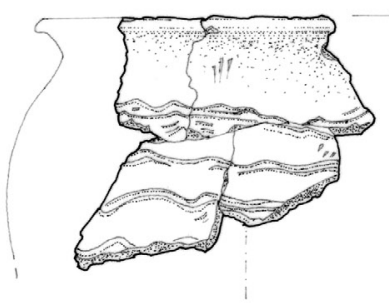

45
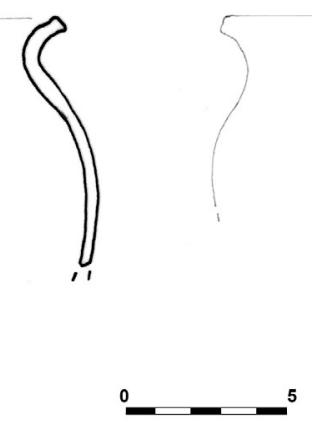

Pl. 5. Virje-Sušine. 34-44: fragments of pottery vessels from SJ 319; 45-46: fragments of pottery vessels from SJ 320.

Tab. 5. Virje-Sušine. 34-44: fragmenty keramických nádob zo stratigrafickej jednotky SJ 319; 45-46: fragmenty keramických nádob zo stratigrafickej jednotky SJ 320. 

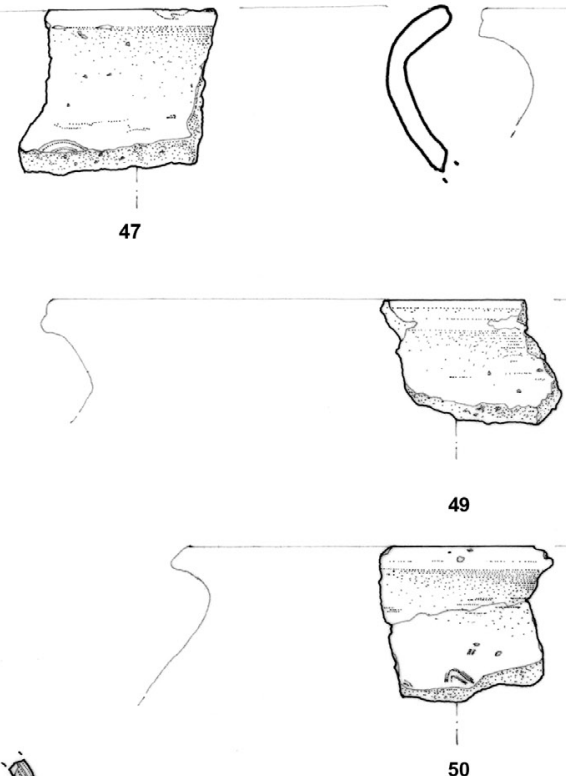

49
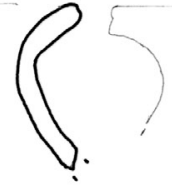

50

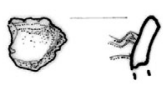

52

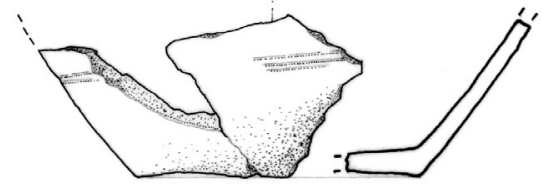

53

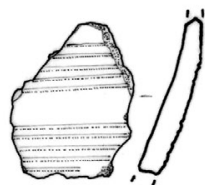

56
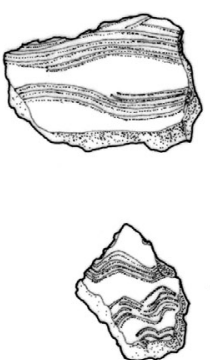

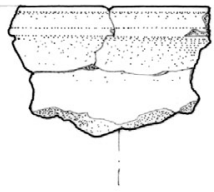

48
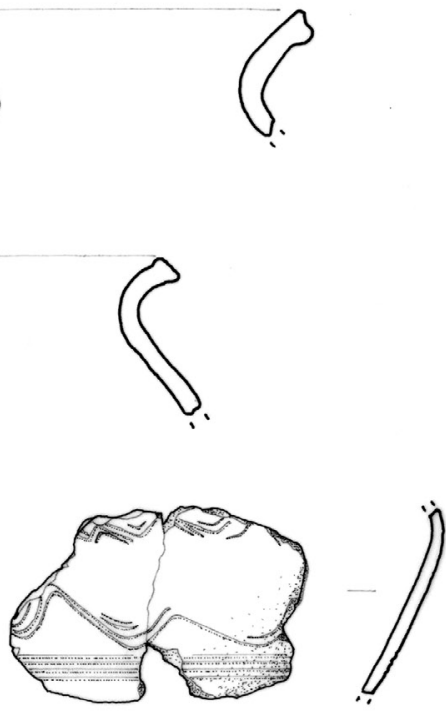

54
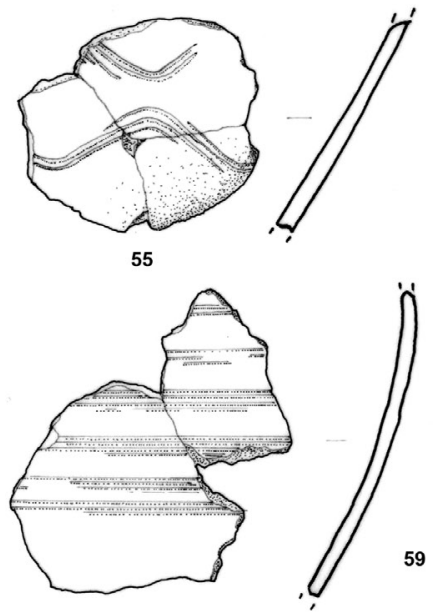

Pl. 6. Virje-Sušine. 47-59: fragments of pottery vessels from SJ 320.

Tab. 6. Virje-Sušine. 47-59: Fragmenty keramických nádob zo stratigrafickej jednotky SJ 320. 


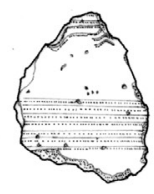

60

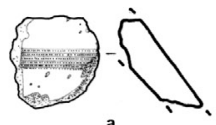

a

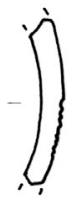

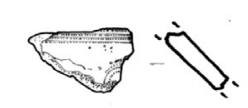

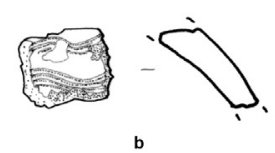

$51 \mathrm{c}$

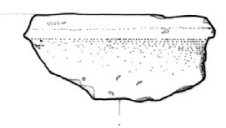

1

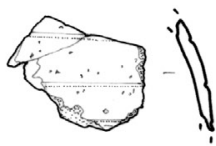

62

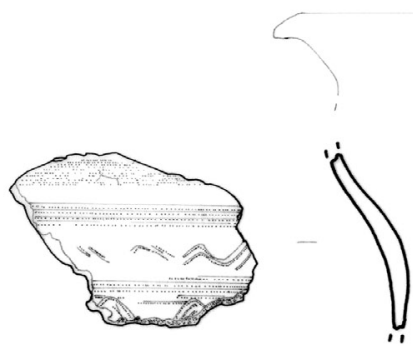

64

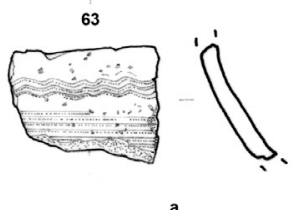

65

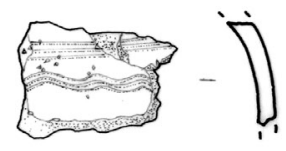

b
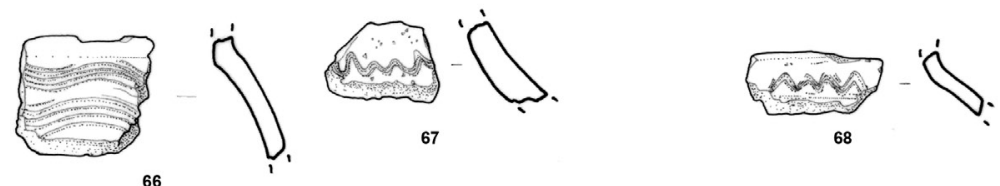

66

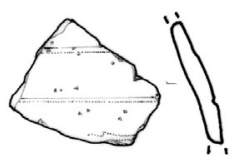

69

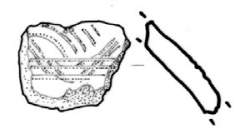

70
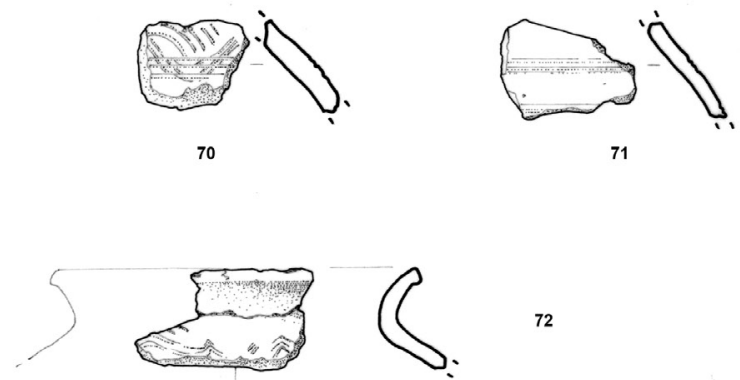

72

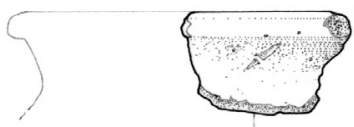

$\int^{73}$

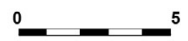

Pl. 7. Virje-Sušine. 60-62: fragments of pottery vessels from SJ 324; 63-65: fragments of pottery vessels from SJ 330; 66-71: fragments of pottery vessels from SJ 001/336; 72-73: fragments of pottery vessels from SJ 336.

Tab. 7. Virje-Sušine. fragmenty keramických nádob zo stratigrafickej jednotky SJ 324; 63-65: fragmenty keramických nádob zo stratigrafickej jednotky SJ 330; 66-71: fragmenty keramických nádob zo stratigrafickej jednotky SJ 001/336; 72-73: fragmenty keramických nádob zo stratigrafickej jednotky SJ 336. 

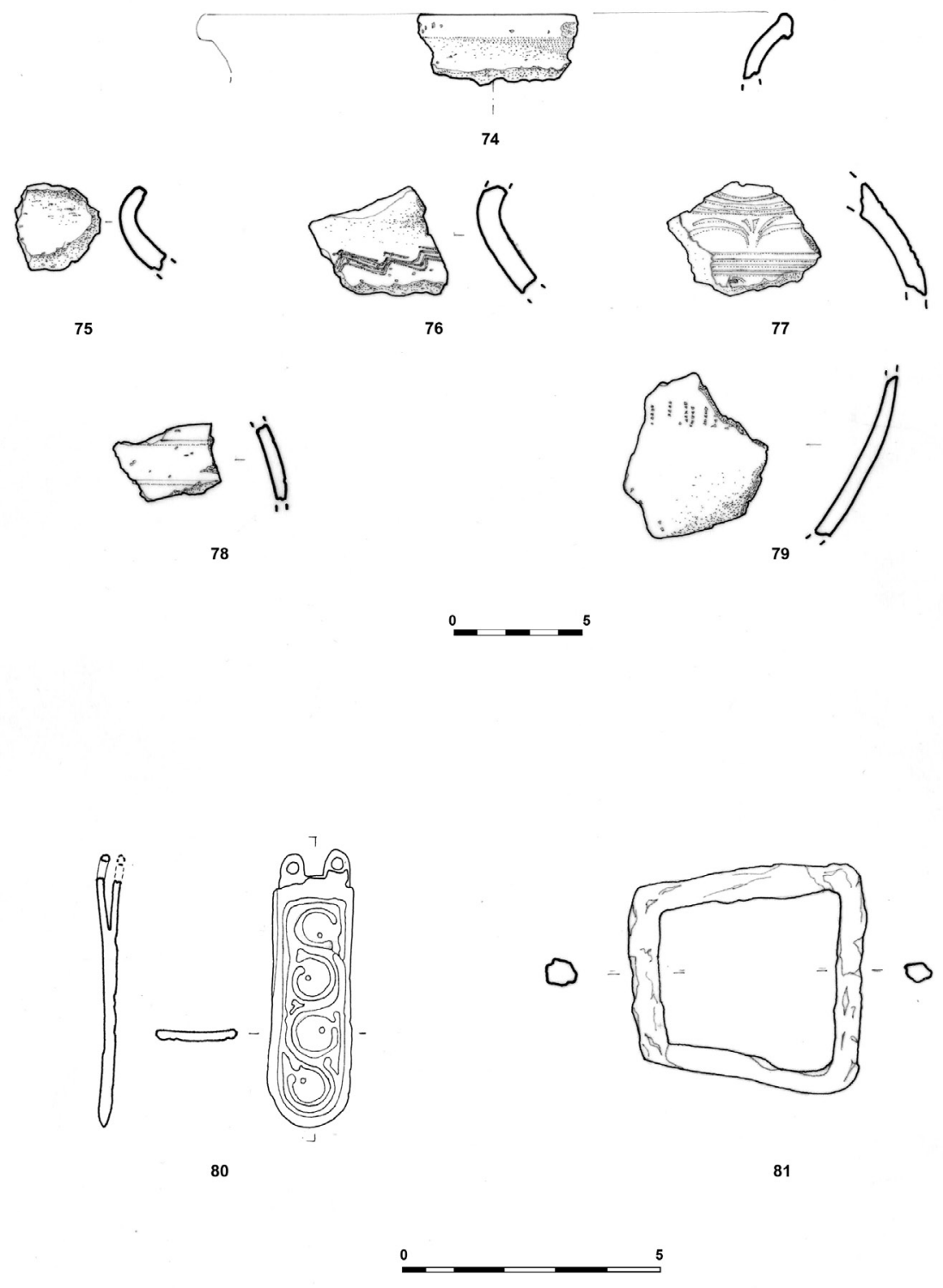

Pl. 8. Virje-Sušine. 74-79: fragments of pottery vessels from SJ 336; 80-81: a bronze strap end and iron buckle from SJ 315.

Tab. 8. Virje-Sušine. 74-79: fragmenty keramických nádob zo stratigrafickej jednotky SJ 336; 80-81: bronzové nákončie a železná pracka zo stratigrafickej jednotky SJ 315. 

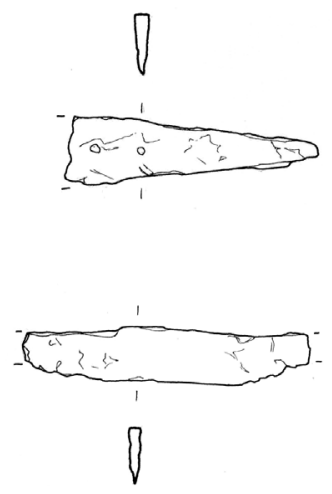

82

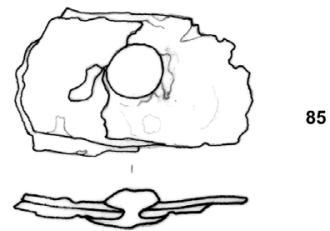

83

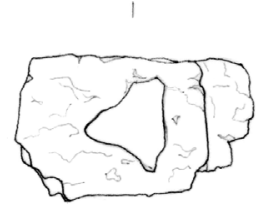

85

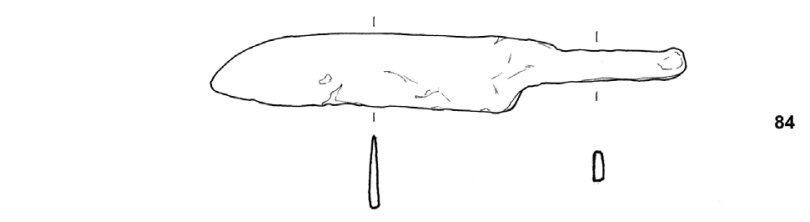

84

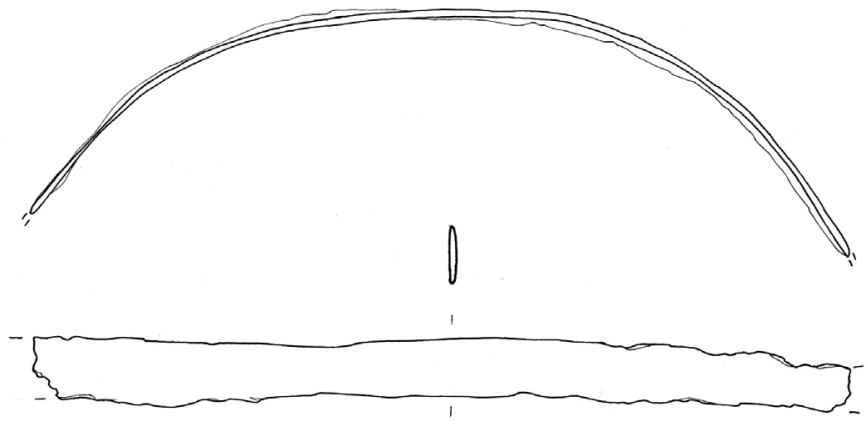

86

87

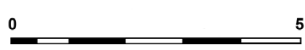

P1. 9. Virje-Sušine. 82-83: fragments of undefined iron objects from SJ 319; 84: an iron knife from SJ 320; 8586: fragments of the hoops of a wooden bucket from SJ 320; 87: fragment of a glass vessel from SJ 001/289.

Tab. 9. Virje-Sušine. 82-83: fragmenty neidentifikovaných železných predmetov zo stratigrafickej jednotky SJ 319; 84: železný nôž zo stratigrafickej jednotky SJ 320; 85-86: fragment obručí dreveného vedra zo stratigrafickej jednotky SJ 320; 87: fragment sklenenej nádoby zo stratigrafickej jednotky SJ 001/289. 